\title{
Discurso publicitario e intertextualidad: \\ itinerarios para la formación comunicativa del profesorado
}

\author{
María del Carmen Quiles Cabrerai(iD \\ Universidad de Almería, Almería, España
}

\begin{abstract}
Resumen
La esencialidad que presenta la didáctica de la lengua y la literatura implica que exista por parte de los docentes un aprendizaje continuo que tenga en cuenta los nuevos espacios y formas de comunicación, así como los mecanismos de innovación educativa. Pero no menos importante es el desarrollo de su propia competencia comunicativa, especialmente en lo que se refiere al ámbito académico. Para ello, en este trabajo ponemos de relieve el papel que cumple el discurso publicitario como eje de secuencias didácticas integradas e interdisciplinares que, mediante un enfoque intertextual, nos permiten reforzar tales destrezas. Tras una aproximación a los textos publicitarios inspirados en cuentos clásicos y referentes artísticos, ofrecemos como resultado las claves didácticas para la formación de maestros/as en habilidades comunicativas.
\end{abstract}

\section{Palabras clave}

Competencia comunicativa. Intertextualidad. Discurso publicitario. Formación del profesorado. Lenguaje académico.

\section{Discurso publicitário e intertextualidade:}

\section{itinerários para formação comunicativa de professores}

\begin{abstract}
Resumo
A essencialidade apresentada pelo ensino da língua e da literatura implica que haja um aprendizado contínuo dos professores que leve em consideração novos espaços e formas de comunicação, bem como mecanismos de inovação educacional. Mas não menos importante é o desenvolvimento de sua própria competência comunicativa, especialmente no que se refere ao campo acadêmico. Nesse sentido, destacamos neste trabalho o papel do discurso publicitário como eixo das sequências didáticas integradas e interdisciplinares que, por meio de uma abordagem intertextual, permitem reforçar essas habilidades. Após uma abordagem aos textos publicitários inspirados em contos clássicos e referências artísticas, oferecemos como resultado as chaves didáticas para a formação de professores em habilidades de comunicação.
\end{abstract}

\section{Palavras-chave}

Competência comunicativa. Intertextualidade. Discurso publicitário. Formação do professorado. Linguagem acadêmica. 


\title{
Advertising discourse and intertextuality: itineraries for communicative teacher training
}

\begin{abstract}
The essentiality presented by language and literature teaching means that learning is continuous on the part of teachers, taking into account new spaces and forms of communication, as well as the mechanisms of educational innovation. But no less important is the development of their own communicative competence, especially in that which refers to the academic field. To this end, in the present work we highlight the role played by advertising discourse as an axis of integrated and interdisciplinary didactic sequences that, from an intertextual standpoint, allows us to reinforce such skills. Following an approach to advertising texts inspired by classic tales and artistic references, we offer the resulting didactic keys for training teachers in communication skills.
\end{abstract}

\section{Keywords}

Communicative competence. Intertextuality. Advertising speech. Teacher training. Academic language.

\section{Introducción: competencia comunicativa y profesorado en formación}

El desarrollo de la competencia comunicativa es el eje central en torno al que giran todos los presupuestos de la didáctica de la lengua y la literatura. Cuando, desde las aulas universitarias, formamos al profesorado de Infantil, Primaria o Secundaria, insistimos en la importancia de desarrollar las destrezas discursivas en los ámbitos formales, dada la dificultad que muchas veces los escolares presentan para separar sus usos académicos del registro coloquial. En el momento en que enfatizamos en estas cuestiones, sale a flote la necesidad de reforzar tales destrezas entre los propios mediadores en formación, como se ha resaltado en trabajos previos (QUILES CABRERA, 2011; ROMERO OLIVA, 2014). Son muy frecuentes las necesidades de mejora en este sentido, las cuales se evidencian fundamentalmente en dos contextos básicos de la Educación Superior: las exposiciones orales y las tareas de investigación (como la elaboración de informes, trabajos de fin de grado o diseños de actuación didáctica). Los pilares básicos de nuestra disciplina - hablar y escuchar, leer y escribir - suponen la implicación de procesos cognitivos superiores, como habían señalado las teorías de Piaget, Vigotsky o Bruner, que evolucionan con el tiempo y que nunca dejan de desarrollarse. Consideramos que es un error ubicar su aprendizaje exclusivo en los primeros niveles educativos, como si, al acabar la escolarización obligatoria, el ser humano dejara de aprender cosas. Estamos en un 
aprendizaje continuo, lo que se llamó aprendizaje a lo largo de la vida (life-long learning) (LÓPEZ-BARAJAS, 2006), lo cual nos lleva a descubrir nuevos contextos comunicativos ante los que hemos de desenvolvernos con soltura; los actuales espacios de interacción en red son una muestra muy visible de cómo la comunicación entre los miembros de una comunidad se ha transformado y, por lo tanto, ha generado distintas formas ante las que los usuarios de la lengua se han tenido que amoldar.

Afirmaba recientemente López Valero (2019, p. 8), en un prólogo fundamental para entender el paradigma de presente y futuro en la didáctica de la lengua y la literatura, que:

\begin{abstract}
En la búsqueda del factor didáctico y de conocimiento que aplicar, desde estas líneas reclamo una formación más completa para los profesionales del área. No es suficiente con la formación inicial de carácter bien filológico o bien pedagógico, ya que, cualquiera de las dos exclusividades plantea un importante problema de falta de recursos en las aulas.
\end{abstract}

Tomando en cuenta esta consideración, quienes se preparan para ser mediadores en educación lingüística y literaria han de tener muy presentes dos elementos:

- Ejercitar su capacidad metacomunicativa para garantizar la implementación de sus propios usos.

- Saber manejar propuestas y recursos eficaces para el desarrollo de habilidades comunicativas en niños y niñas.

No nos cabe duda de que, para alcanzar esos dos objetivos claros, la incorporación del discurso publicitario nos abre múltiples posibilidades, dado su carácter multimodal, transversal e interdisciplinar. Estos textos - tanto en su versión gráfica como audiovisual - nos permiten el desarrollo integrado de competencias, avanzando desde elementos meramente relacionados con el código lingüístico a los pragmático-discursivos y sociolingüísticos, y estableciendo puentes con la competencia literaria. Al estudiante que manifiesta poco interés hacia obras clásicas, como puede ser Alicia en el país de las maravillas, y descubre en el aula que una conocida línea de supermercados británica en una de sus campañas se centra en su protagonista ${ }^{1}$ el camino se hace menos tortuoso y el acceso mucho más fácil y atractivo. Y, durante el recorrido, el desarrollo de destrezas comunicativas que podemos lograr es muy amplio.

1 También reconocemos a Alicia - junto a Caperucita y Blancanieves - en la colección de vinos, Vinos de cuento, distribuida en España por los frecuentados supermercados de origen valenciano.

Educ. Form., Fortaleza, v. 6, n. 1, e3455, jan./abr. 2021

DOI: https://doi.org/10.25053/redufor.v6i1.3455

https://revistas.uece.br/index.php/redufor/index 


\section{Metodología}

El trabajo que presentamos obedece a una metodología basada en distintos enfoques, combinando la investigación descriptiva y exploratoria de documentos con el paradigma de investigación de diseño. Por un lado, el rastreo y búsqueda de testimonios publicitarios en conexión con referentes literarios clásicos y/o artísticos (marcados por un carácter intertextual) a través de motores de búsqueda on line. En segundo lugar, tras sentar las bases epistemológicas del concepto intertextualidad y ejemplificarlo, hemos procedido al análisis y reflexión crítica de los documentos más representativos para ofrecer las claves al mediador/a sobre cómo leer el texto publicitario. Por último, diseñamos de forma sintética diversas líneas de trabajo ejemplificadoras para el aula universitaria centrada en la formación del profesorado.

\section{Intertextualidad y discurso publicitario}

\subsection{Los textos hablan entre sí}

El hecho de que los textos se hablan entre sí y se entretejen, como si de un tapiz se tratara, no es una cuestión nueva. Es bien conocido que Julia Kristeva acuñó el término "intertextualidad" (1967), siguiendo los postulados bajtinianos y, junto a ella, Roland Barthes (1968), Arrivé (1973), Dällenbach (1976) y Genette (1989), entre otros, que destacarían ese diálogo textual que vendría de la imitatio clásica y que en nuestros días se actualiza con el reconocimiento de unos referentes discursivos en otros. Los textos se producen sobre lo ya construido, esto es, establecen una recreación de voces o imágenes que ya fueron perfiladas y que nuestro intertexto lector va a identificar en muchas ocasiones. Más adelante el concepto ha sido abordado en la evolución de la teoría literaria y la literatura comparada, a través de las investigaciones de autores como Vázquez Medel (1995), Martínez (2001) y Lara (2007), entre otros. Además, Mendoza Fillola (1994, 2003) y Durañona y otros (2006) fueron marcando el terreno de actuación a la hora de entender el carácter intertextual de los discursos y su potencial didáctico en educación lingüística.

En nuestras aportaciones previas en torno a esta temática (QUILES CABRERA, 2010, 2012), ya veníamos poniendo de relieve el potencial pedagógico del enfoque 
intertextual e interdisciplinar en nuestra área de conocimiento. La conexión entre las diversas artes y disciplinas, así como la inclusión misma de estos ámbitos en los discursos que explican los acontecimientos sociales - como la prensa o los textos urbanos -, es muy evidente y frecuente. $Y$ esta vinculación nos ayuda a entender el mundo, a conformar nuestro propio criterio y concepción de los hechos que nos rodean. Recordemos el cartel en el que se recurría al personaje fílmico de King-Kong para referirse a la tragedia del 11 de septiembre:

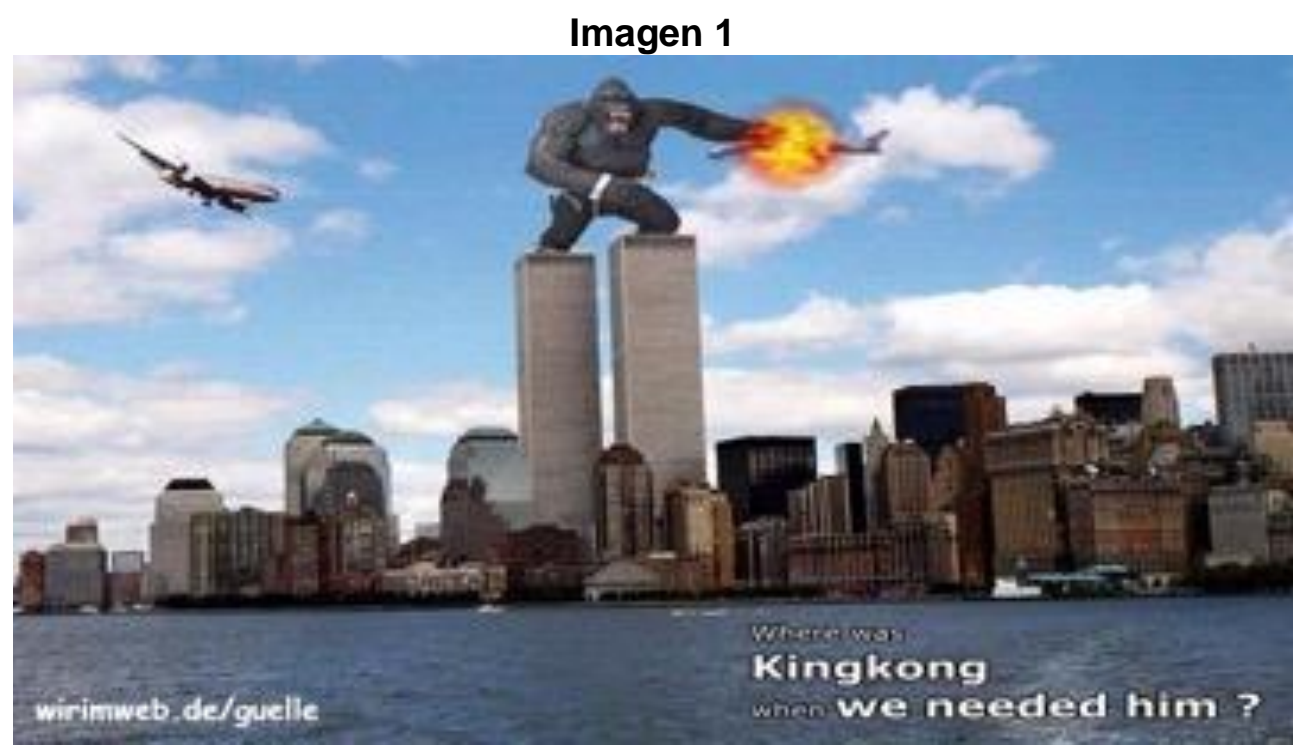

Fuente: Extraída de páginas de acceso libre a través de Google.

El imaginario colectivo alberga un sinfín de elementos artísticos o culturales que, heredados del cine, de la historia del arte, de la música o de la literatura, activa el intertexto de los lectores estableciendo puentes que nos llevan desde un ámbito al otro. Como en el ejemplo anterior, un interrogante - las palabras - y una imagen establecen un diálogo entre la realidad y un clásico fílmico para aludir a una catástrofe terrorista que sobrecogió a todo el planeta.

Recordemos también el homenaje que la popular serie de televisión Los Simpson realizó al mundo del arte, incorporando guiños a grandes pinturas y referentes cinematográficos en algunos de sus capítulos. El ejemplo más representativo es el de su entrega especial por el Hallowen de 1993, en el que nos encontramos con obras de diversos pintores, como es el caso de Dalí, cuya obra titulada El sueño es recreada de la siguiente forma:

Educ. Form., Fortaleza, v. 6, n. 1, e3455, jan./abr. 2021 


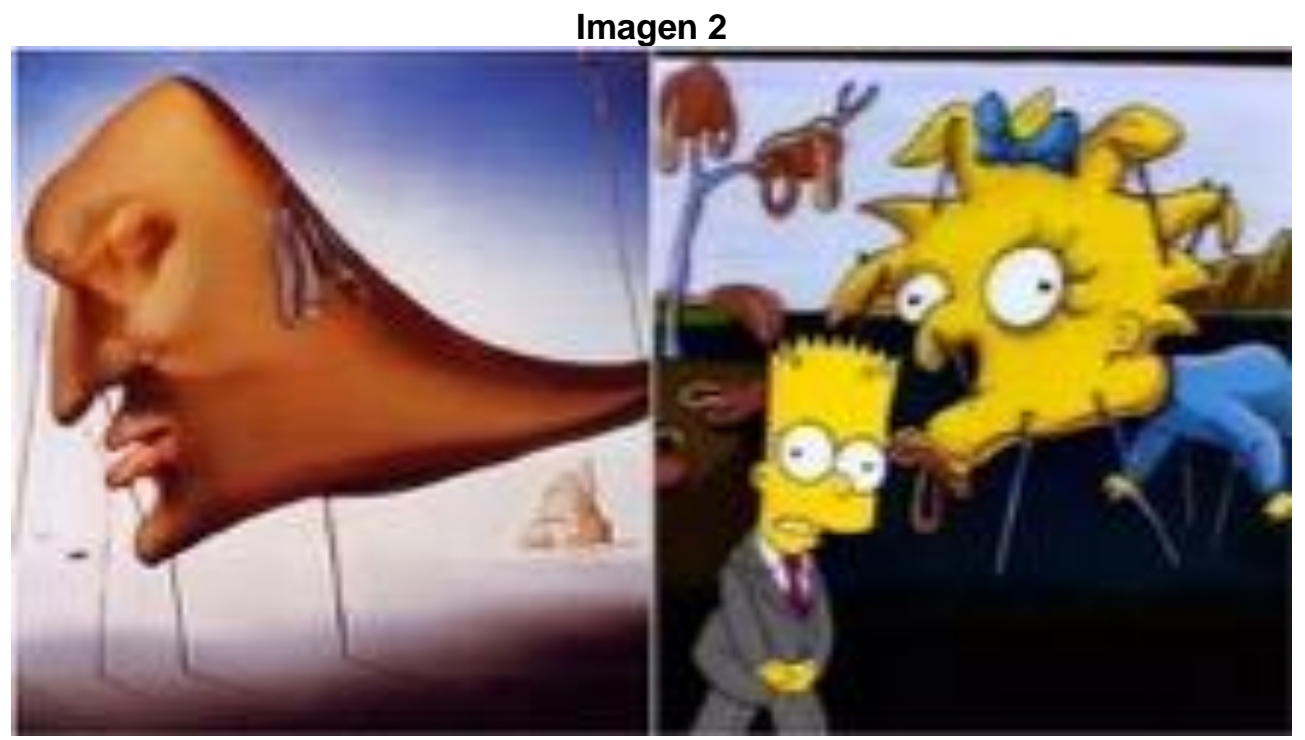

Fuente: https://www.lacamaradelarte.com/2018/12/simpsons-historia-arte.html.

Otro ejemplo podría ser el fotograma donde la señora Simpson reproduce la estampa de Mujer ante el espejo, de Norman Rockwell:

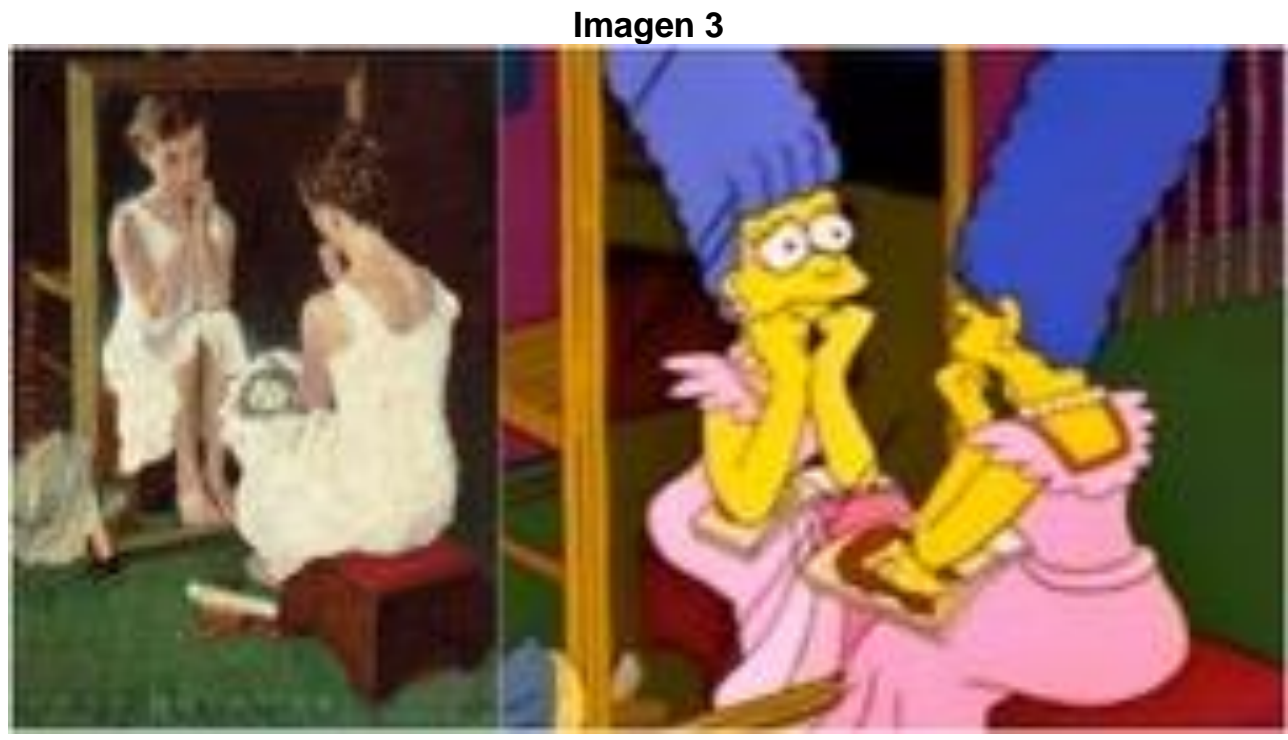

Fuente: https://culturacolectiva.com/arte/25-obras-de-arte-que-aparecen-en-los-simpson.

La intertextualidad y la interdisciplinariedad en esta serie de animación han sido estudiadas en trabajos muy interesantes, como los de Gray (2006), Martín, A. y Martín, M. (2010), Horacio Sánchez (2010), Enríquez Veloso (2012), García Torralbo (2013), Irwin, Conard, y Skoble (2009), Rodríguez Arrieta (2015) o Del Río (2017).

Por su parte, los textos publicitarios tampoco quedan ajenos a ese diálogo discursivo al que nos venimos refiriendo. El estudio de la publicidad se ha venido

Educ. Form., Fortaleza, v. 6, n. 1, e3455, jan./abr. 2021

DOI: https://doi.org/10.25053/redufor.v6i1.3455

https://revistas.uece.br/index.php/redufor/index 
haciendo desde hace mucho tiempo y desde perspectivas muy diferentes. Dentro de la didáctica de la lengua y la literatura, hemos de mencionar, sin duda, los trabajos de Lomas (1993, 1996, 2001) y Sánchez Corral (1991, 1997, 2006), que, tomando los presupuestos de la semiótica y la retórica publicitaria, abrían una puerta al análisis de estos textos con perspectiva educativa. En los últimos años, son también de gran interés los trabajos de López $(2017,2020)$ y Martínez Ezquerro $(2012,2021)$. Hoy sabemos de la importancia de aprender a leer la publicidad como una forma de entender el mundo que nos rodea desde la crítica y el compromiso social; el discurso publicitario conlleva toda una estética donde nada es inocente y donde las imágenes y las palabras confluyen para llamar a la puerta de los lectores - consumidores en potencia.

Cómo iba a imaginar Leonardo Da Vinci que, mucho tiempo después de pintar su Mona Lisa, McDonalds haría una campaña publicitaria usándola como referente y tratando de "desvelar" el porqué de su sonrisa. En la imagen 4 observamos uno de los fotogramas del vídeo que puede encontrarse completo en la plataforma YouTube. $Y$ tampoco Diego Velázquez pudo vislumbrar que sus Meninas se tomarían como inspiración para que prestigiosas marcas y algunas firmas de moda se dieran publicidad. En la imagen 5 tomamos un ejemplo en el que el eslogan "Welcome where the fashion is art' juega enlazando dos ámbitos artísticos: la moda y la pintura.

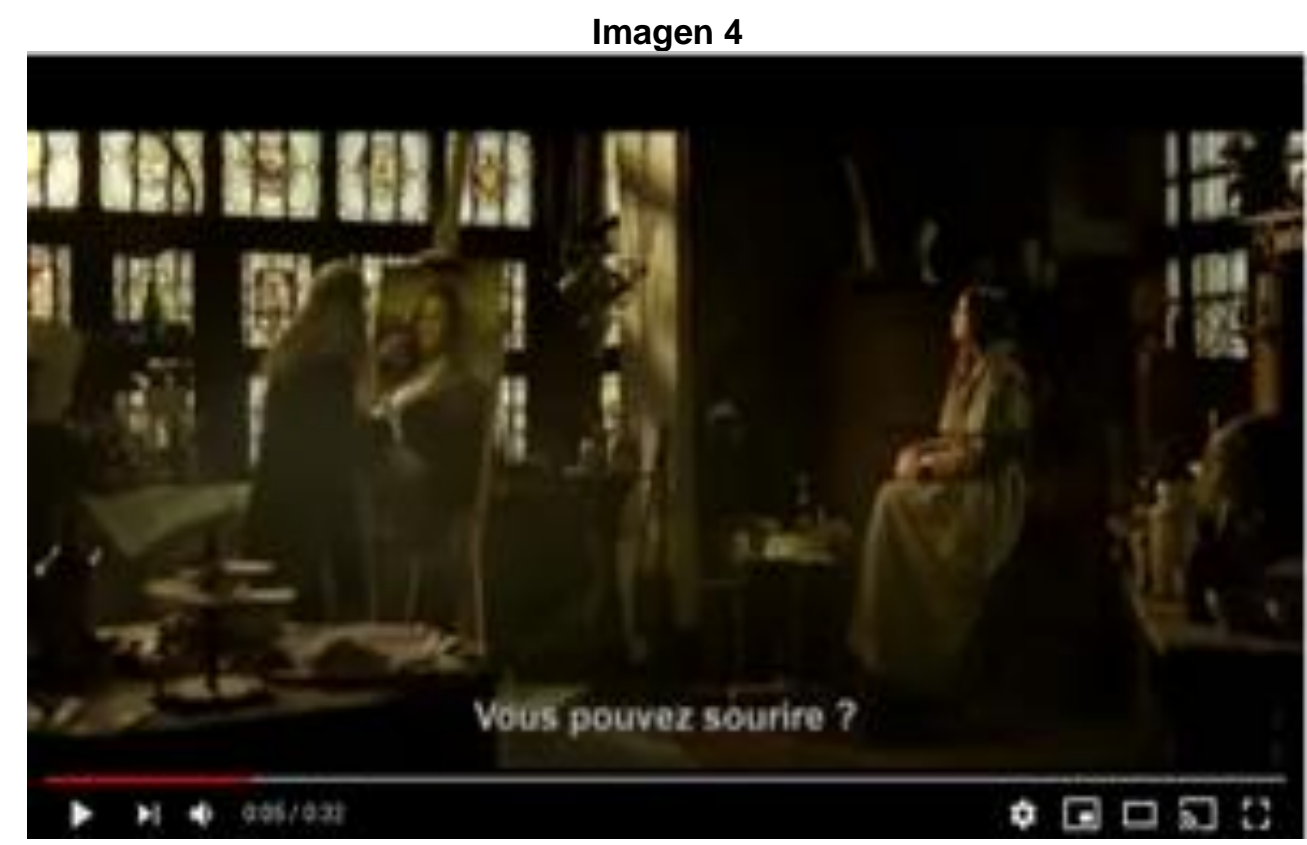

Fuente: https://www.youtube.com/watch?v=afLsk1lksB0.

Educ. Form., Fortaleza, v. 6, n. 1, e3455, jan./abr. 2021

DOI: https://doi.org/10.25053/redufor.v6i1.3455

https://revistas.uece.br/index.php/redufor/index 
Imagen 5

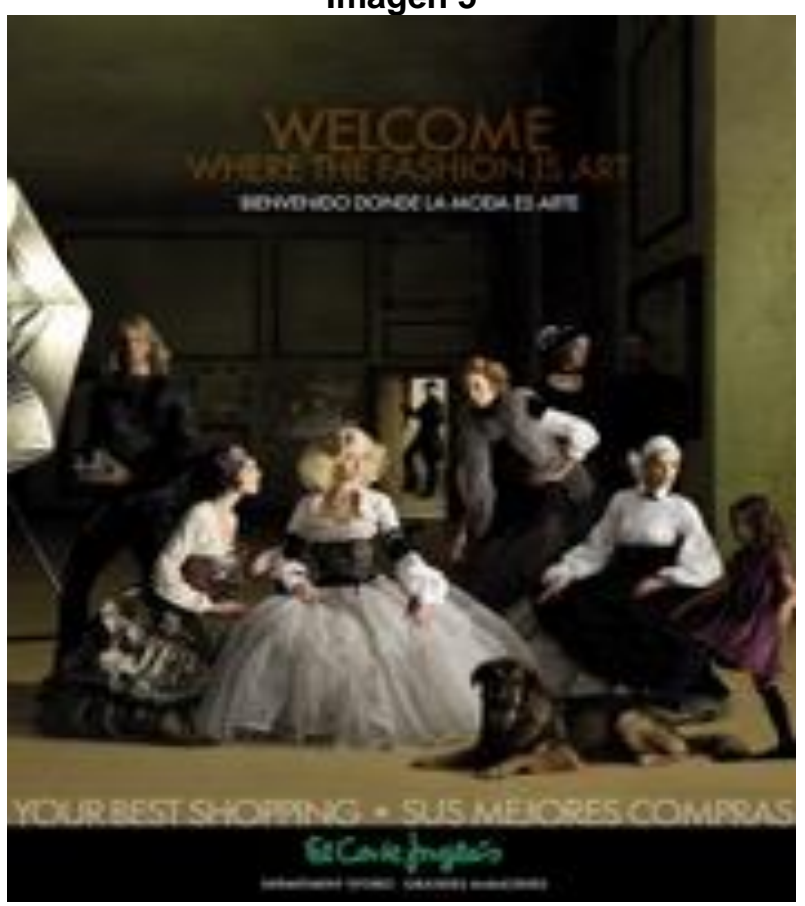

Fuente: http://www.google.es.

Las ninfas, personajes de la literatura tradicional asociados al agua y los espacios naturales (FERNÁNDEZ-FíGARES; GARCÍA RIVERA, 2017; MARTOS NÚÑEZ, 1997; MARTOS-GARCíA, A.; MARTOS-GARCÍA, A. E., 2019a), son retomadas en anuncios actuales por firmas como Dior o Guchi para publicitar sus perfumes. En ambas, se alude a mujeres dentro de un mismo canon de belleza, enmarcadas en un ambiente acuático que nos transporta al locus amoenus clásico:

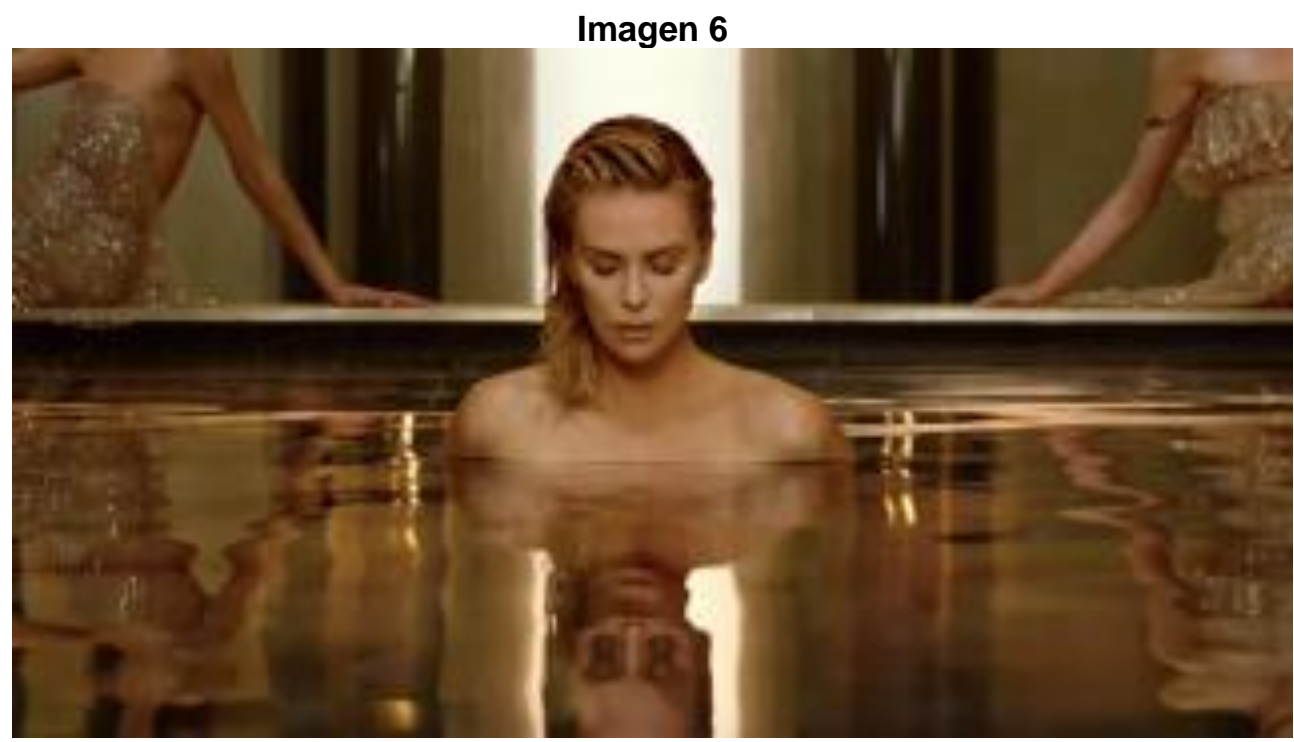

Fuente: https://www.youtube.com/watch?v=ovg965vHyeU.

Educ. Form., Fortaleza, v. 6, n. 1, e3455, jan./abr. 2021

DOI: https://doi.org/10.25053/redufor.v6i1.3455

https://revistas.uece.br/index.php/redufor/index ISSN: 2448-3583

CC) (i) Esta obra está licenciada com uma Licença Creative Commons 


\section{Imagen 7}

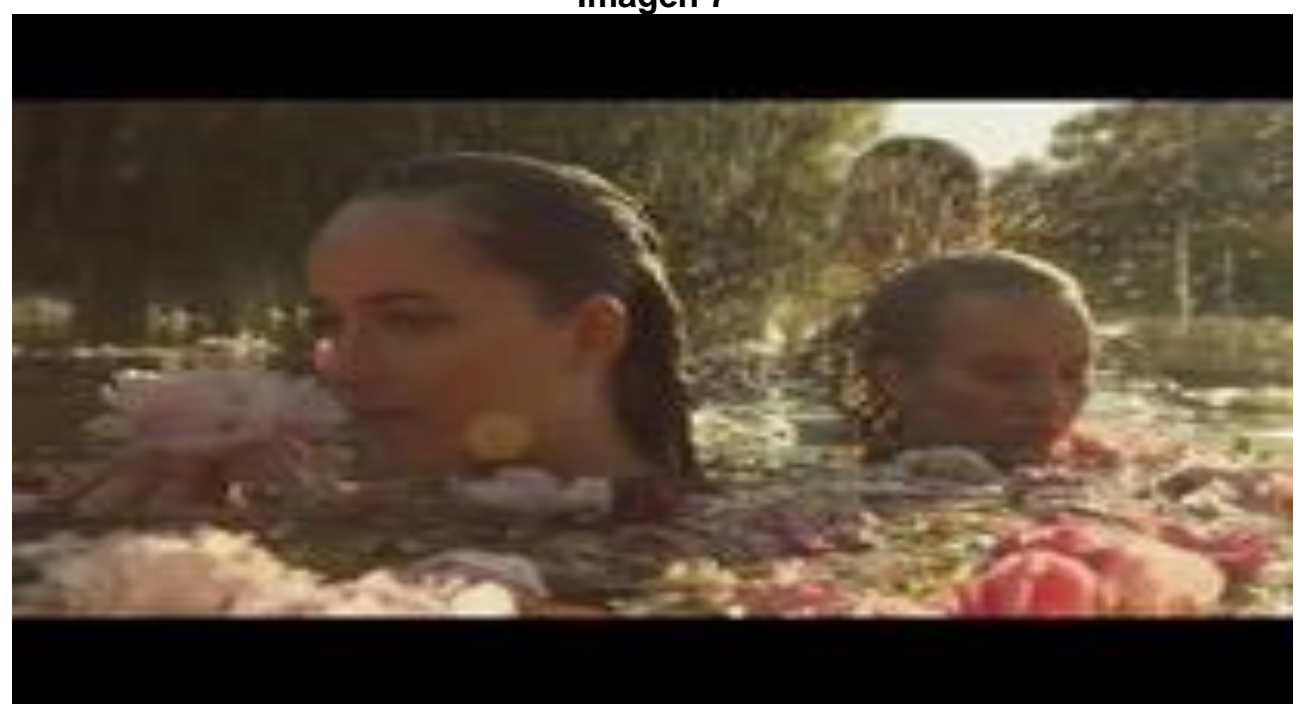

Fuente: https://www.youtube.com/watch?v=wafe6kDBb6c.

Todo ello viene unido a la idea de culto al cuerpo, a lo material, que nos remonta a una concepción narcisista de la vida, muy habitual en los productos de cosmética, no solo dirigidos a mujeres, sino también a hombres, buscando la eterna juventud como Perséfone y persiguiendo estelas de los grandes héroes mitológicos (CABALLERO, 2010; FREIRE, 2014; MONTOYA, 2015). Pensemos en la publicidad de perfumes masculinos de los últimos años, como es el caso de la firma Jean Paul Goultier o Armani, entre otras:

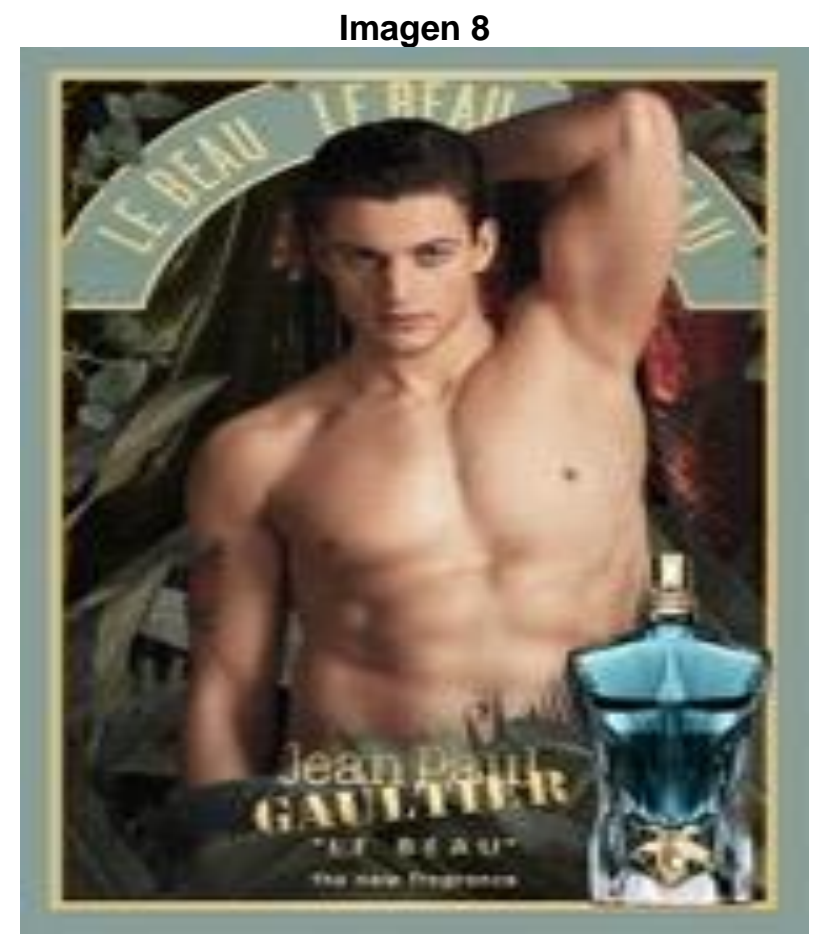

Fuente: http://www.google.es.

Educ. Form., Fortaleza, v. 6, n. 1, e3455, jan./abr. 2021

DOI: https://doi.org/10.25053/redufor.v6i1.3455

https://revistas.uece.br/index.php/redufor/index 


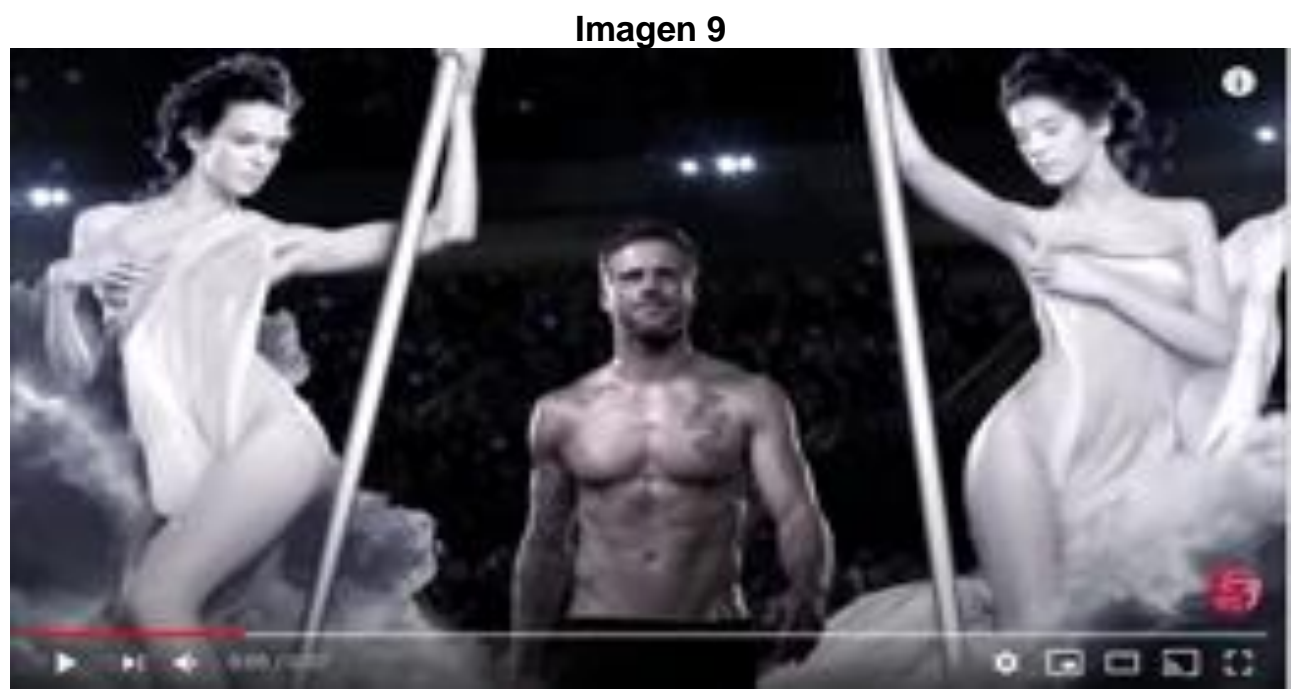

Fuente: https://www.youtube.com/watch?v=vnoztsk0grs.

\subsection{Algunos clásicos literarios infantiles en la publicidad}

Al hilo de todo lo anterior, somos conscientes de que la publicidad actual acude en muchos casos a los clásicos infantiles de la literatura universal como eje del discurso, sobre el cual edifica tanto el eslogan como toda la iconografía que lo integra. Por un lado, podemos volver la vista a las campañas de concienciación en torno a temáticas muy diversas, como el propio fomento de la lectura, donde se nos presentan personajes enfermos por la falta de hábito lector, o la concienciación ecológica a través de protagonistas de gran éxito y afinidad con la infancia:

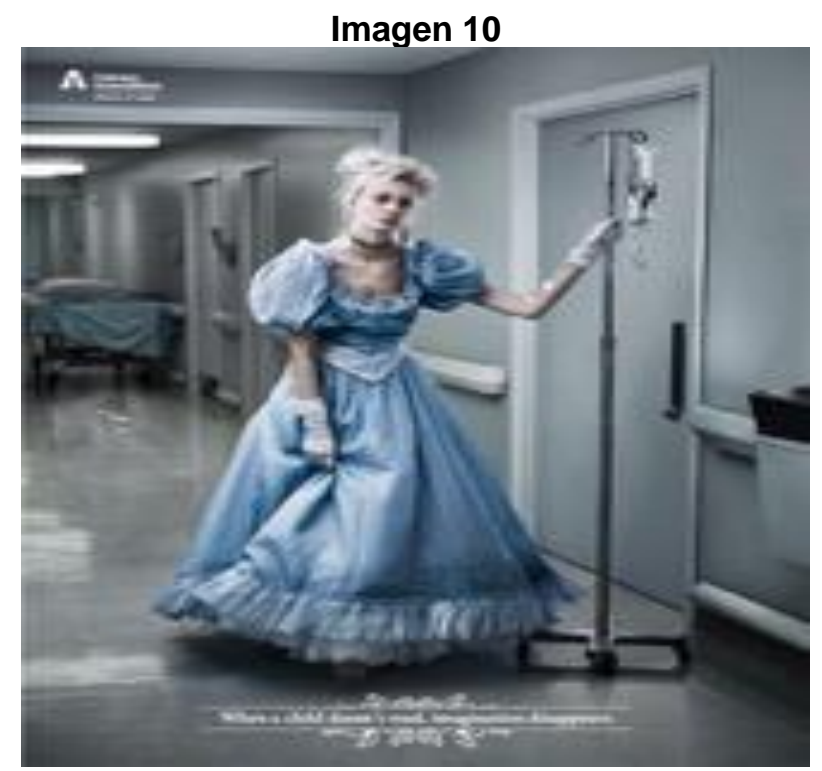

Fuente: https://bibliocriptana.wordpress.com/2008/11/26/cenicienta-cuando-un-nino-no-lee-la-imaginaciondesaparece/.

Educ. Form., Fortaleza, v. 6, n. 1, e3455, jan./abr. 2021

DOI: https://doi.org/10.25053/redufor.v6i1.3455

https://revistas.uece.br/index.php/redufor/index 


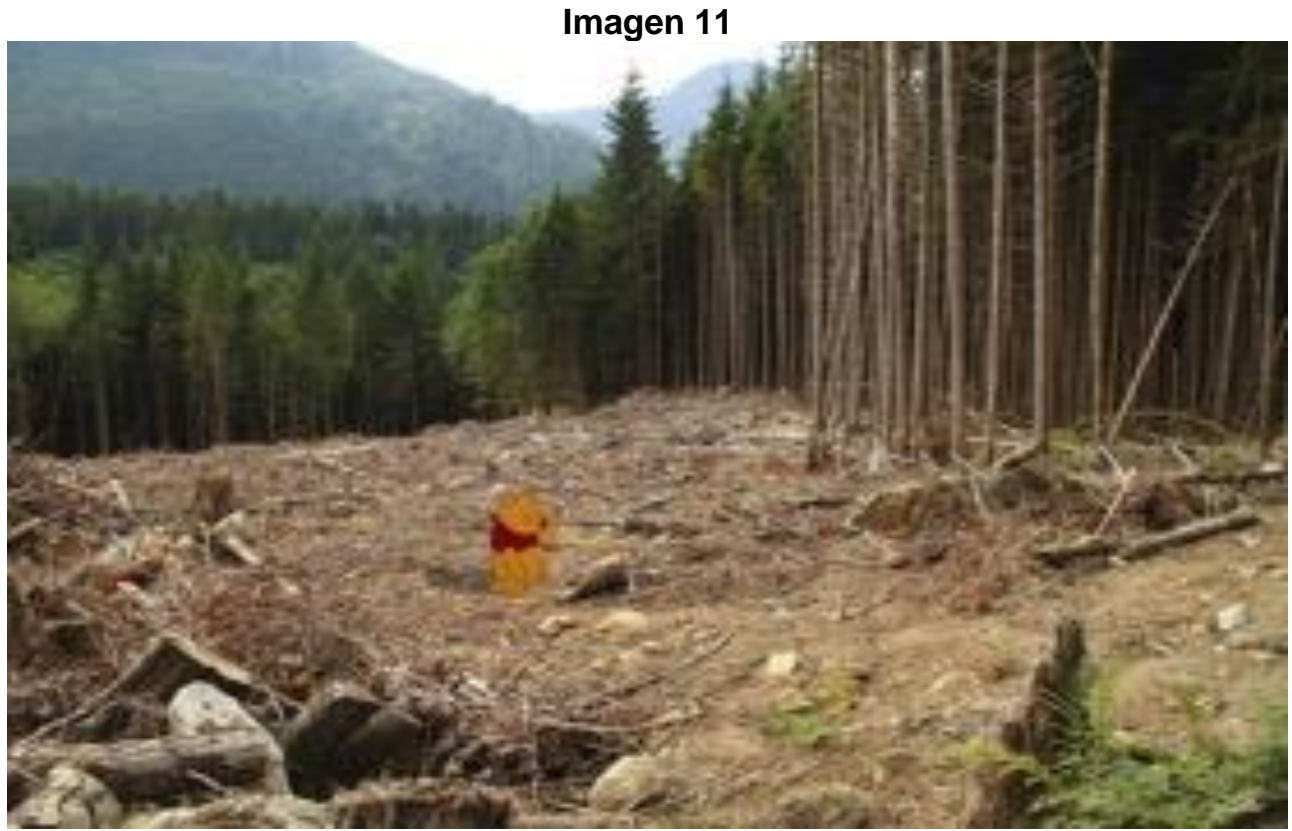

Fuente: https://www.elsiglo.mx/galeria/7945-2665026.personajes-de-disney-infelices-para-siempre.

Pero donde es mucho más frecuente es en la publicidad comercial, que busca la venta de un determinado producto, y no necesariamente para público infantil. Las princesas clásicas son las preferidas en muchos casos. Veamos los siguientes ejemplos de publicidad gráfica en los que se toman como referentes a La bella durmiente, Caperucita, La Cenicienta, Rapunzel y La Sirenita:

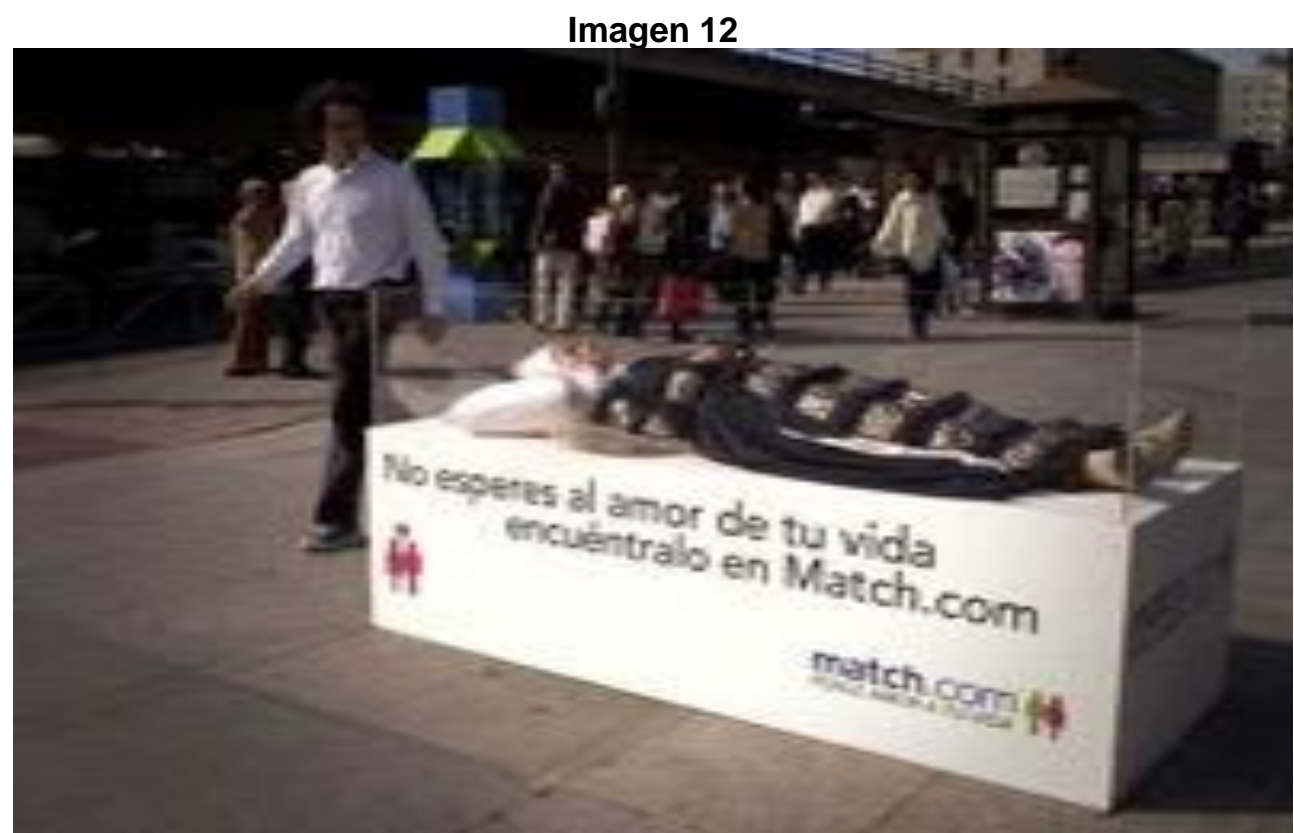

Fuente: https://elpais.com/diario/2005/12/31/sociedad/1135983609_850215.html.

Educ. Form., Fortaleza, v. 6, n. 1, e3455, jan./abr. 2021

DOI: https://doi.org/10.25053/redufor.v6i1.3455

https://revistas.uece.br/index.php/redufor/index 
Imagen 13

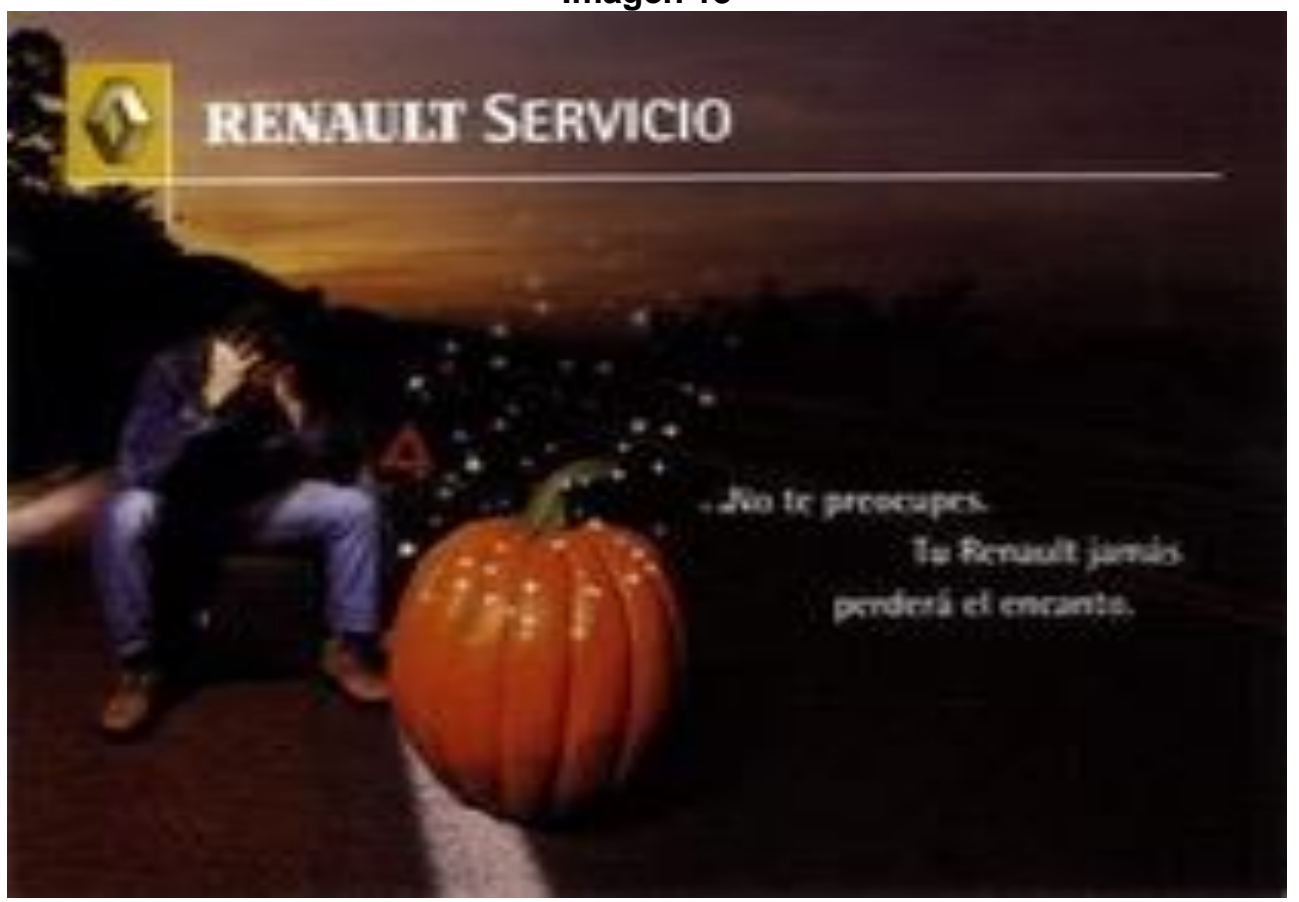

Fuente: http://www.google.es.

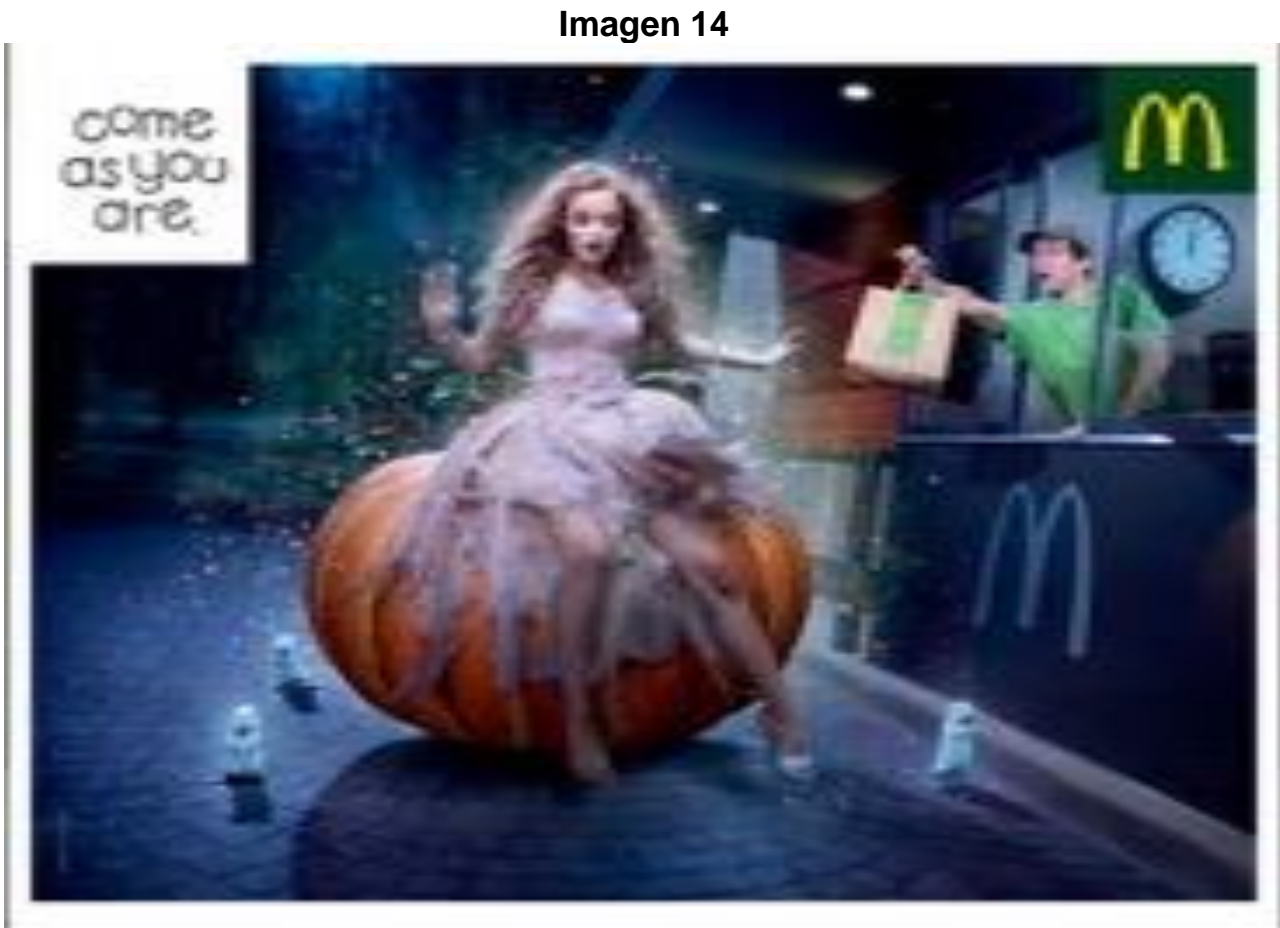

Fuente: http://www.google.es.

Educ. Form., Fortaleza, v. 6, n. 1, e3455, jan./abr. 2021

DOI: https://doi.org/10.25053/redufor.v6i1.3455

https://revistas.uece.br/index.php/redufor/index 


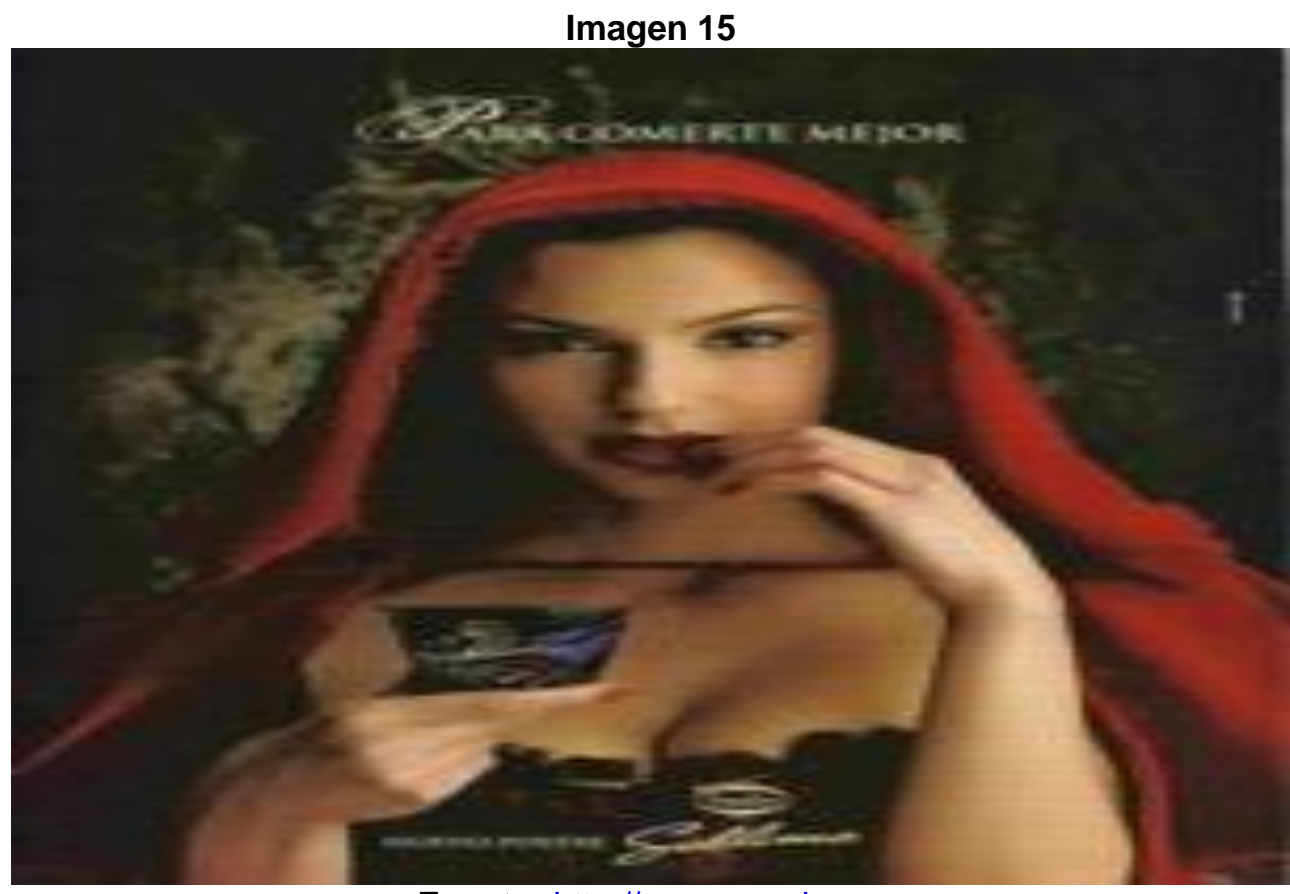

Fuente: http://www.google.es.

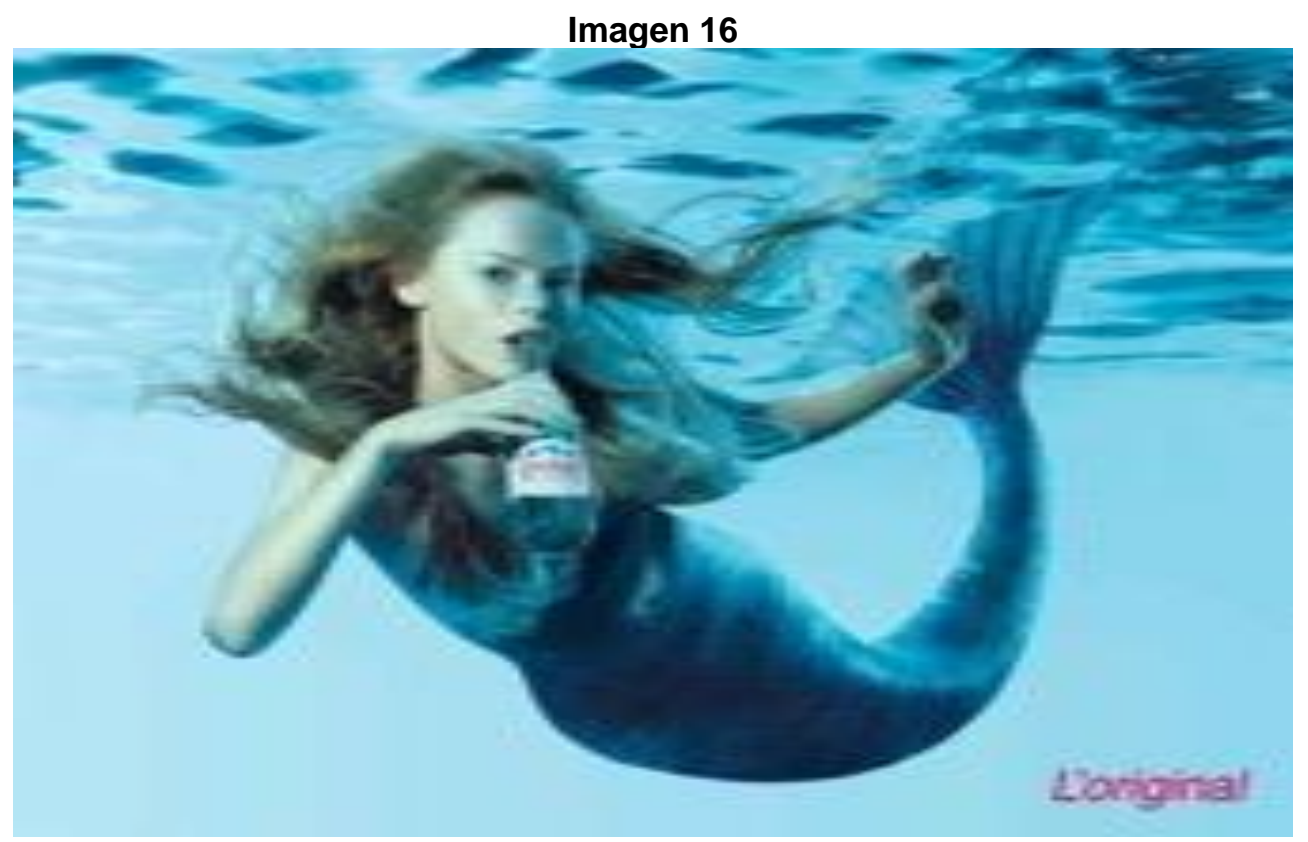

Fuente: http://www.google.es.

De igual forma, esta recurrencia a los clásicos infantiles también es muy frecuente en textos publicitarios audiovisuales, como el conocido anuncio del perfume de Chanel en el que Caperucita manda callar al lobo - gracias al poder del producto, claro está -, o de una marca de accesorios de peluquería como GHD que encontró en Rapunzel y $\mathrm{La}$ Cenicienta un buen modelo sobre el que sustentar su campaña, con el lema "You can do anything with your hair". De alguna manera se apela a la emoción, a los sentimientos de

Educ. Form., Fortaleza, v. 6, n. 1, e3455, jan./abr. 2021

DOI: https://doi.org/10.25053/redufor.v6i1.3455

https://revistas.uece.br/index.php/redufor/index 
felicidad asociados con la infancia para captar la atención del consumidor adulto. Para la visualización completa de ambos vídeos, hemos de acceder a los enlaces².

De igual forma, la referencia a Alicia es del todo evidente en la campaña navideña de 2013 de los supermercados británicos Marc and Spencer, en el que la protagonista cae al vacío por una tapa de alcantarilla llegando a un mundo mágico, con múltiples alusiones a la obra de Carroll ${ }^{3}$.

Santos Recuenco (2019) realiza una muy interesante aproximación a cómo la publicidad busca en las fuentes literarias de los clásicos infantiles y juveniles sus motivos de inspiración para las campañas de muy diversas firmas. Por un lado, resalta la presencia de héroes y heroínas del cómic y, por otro, las y los protagonistas de los cuentos tradicionales. Concretamente, destacamos el análisis que realiza a propósito de Hèrmes, destinada a complementos de lujo bajo el lema "La vida como un cuento". El zapato perdido de La Cenicienta, la alfombra de Aladino, la imagen de la Sirenita o la baraja de Alicia, entre otros, saltan a vista con una simple ojeada al publicitar cada uno de sus productos. Veamos algún ejemplo:

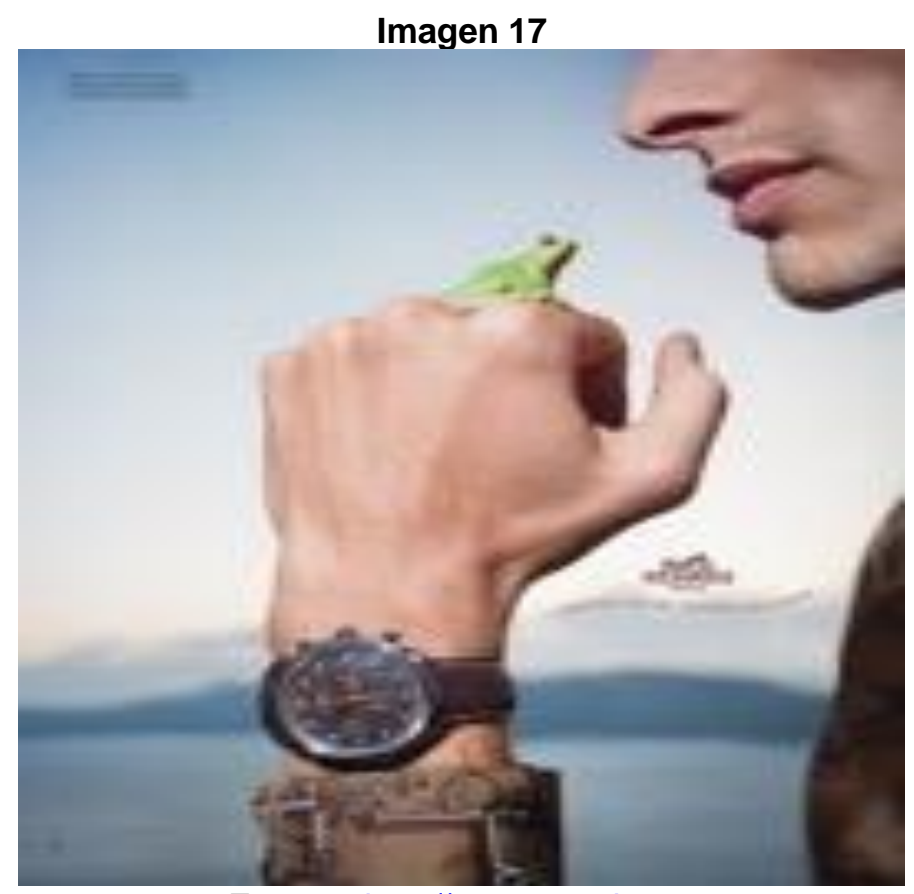

Fuente: http://www.google.es.

2 En: https://www.youtube.com/watch?v=0tqx9pctbwg y https://www.youtube.com/watch?v=5arv9hzsd-c, respectivamente.

3 Podemos visualizar el vídeo completo en: https://www.youtube.com/watch?v=a2qlwdyfinc.

Educ. Form., Fortaleza, v. 6, n. 1, e3455, jan./abr. 2021

DOI: https://doi.org/10.25053/redufor.v6i1.3455

https://revistas.uece.br/index.php/redufor/index 


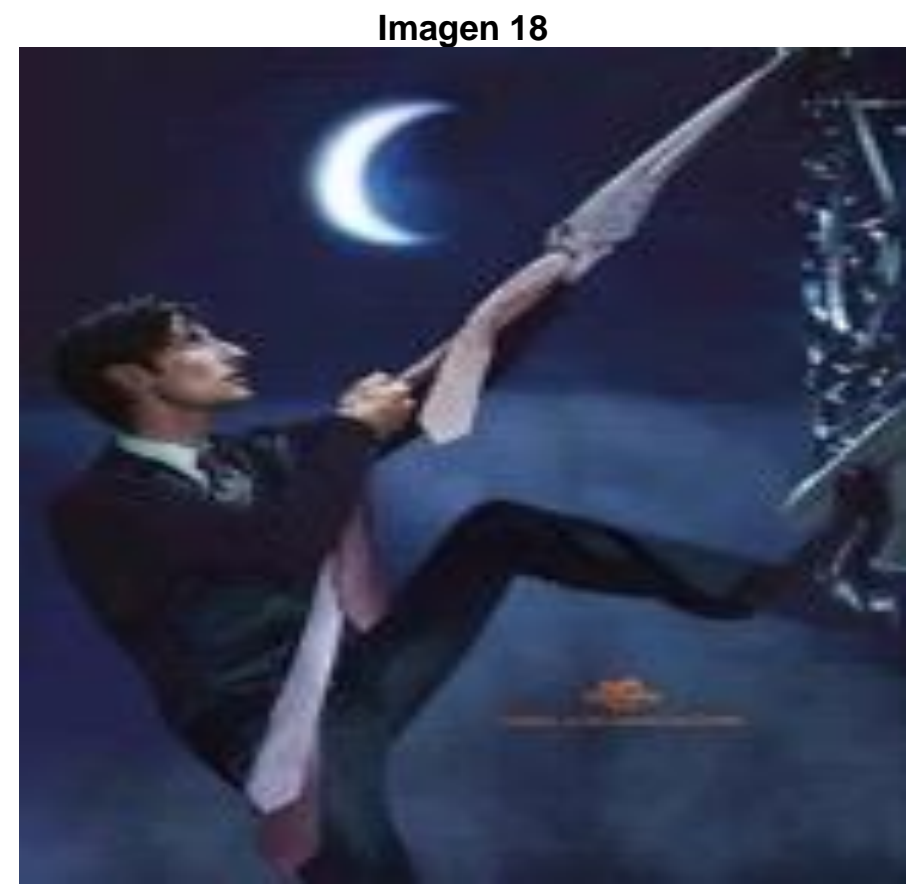

Fuente: http://www.google.es.

\section{4 ¿Qué nos cuentan estos anuncios?: claves discursivas para tener en cuenta en la formación de maestros/as}

El discurso publicitario ha sido estudiado y analizado por numerosos especialistas, entre los que podemos destacar a Robles Ávila $(2004,2014)$. En esta ocasión, nos vamos a detener en las claves discursivas que se ponen de relieve en los anuncios mencionados en el apartado precedente, esto es, vamos a reflexionar sobre qué nos cuentan y cómo nos lo cuentan, para hacer una lectura en clave didáctica de los textos en cuestión. Todos ellos ofrecen un relato en el que el objetivo final es realzar el producto que ofertan al mercado, usando un esquema narrativo vinculado a una historia fácil de reconocer o muy accesible por el lector. $Y$ en ese esquema intervienen tres elementos fundamentales, que están presentes tanto en los anuncios gráficos como en los audiovisuales (que cuentan con el añadido de los efectos de voz y sonido/música):

- Las imágenes explícitas: lo que vemos.

- El eslogan o texto general: lo que "leemos" o escuchamos.

- Los referentes inferidos: lo que se esconde detrás de las imágenes y las palabras, donde entra en juego el carácter multimodal del texto publicitario recordemos la aportación de López (2020).

Educ. Form., Fortaleza, v. 6, n. 1, e3455, jan./abr. 2021 
Tomemos como ejemplo el anuncio recogido en la imagen 15, en el que el hechizo de Cenicienta se está deshaciendo porque han dado las doce campanadas, al tiempo que ella recoge su pedido en un conocidísimo restaurante de comida rápida:

- ¿Qué vemos?: una chica joven rodeada de un brillo mágico, una calabaza, unos ratones, un camarero, una bolsa de comida, un reloj con las agujas en las doce y el logo de la marca de manera bien visible.

- ¿Cuál es el eslogan que podemos leer?: "Come as you are”, un mensaje que apela a la propia identidad, a la autoafirmación de la personalidad de cada cual, en definitiva, a la autenticidad. Los publicistas quieren ofrecer una imagen de comida sana, sin artificios, de carácter "natural", como lo es Cenicienta antes y después del baile; sin embargo, este mensaje contrasta con el dudoso carácter saludable de sus productos.

- ¿Qué referentes inferimos?: todos los elementos nos conducen al cuento de Cenicienta: tenemos a la protagonista, también a un supuesto príncipe y un elemento que se olvida, no solo el zapato, sino la bolsa de comida que la chica no llega a coger y queda pendiente de la mano del chico. Vemos de forma evidente cómo la calabaza o los ratones son elementos explícitos que nos dan la pauta para identificar el cuento clásico.

En definitiva, el anuncio nos cuenta la historia de nuevo, la relee y la actualiza, acercándola a sus intereses comerciales y, al mismo tiempo, atrayendo al potencial consumidor, que va a reconocer el cuento clásico desde el comienzo, algo que no solo hará el niño o adolescente, sino también el adulto que va a acompañarlo.

En la imagen 19, también queda patente el producto de venta: una prenda de vestir masculina como es la corbata. Esta constituye la imagen central que nos va a conducir a la historia de Rapunzel, sin necesidad de que la princesa clásica aparezca en ningún momento. Tenemos un príncipe y también una torre que pretende escalar, y el elemento clave de ese cuento clásico, que es la larga cabellera de la protagonista, se ha transformado en el objeto publicitado: las corbatas, que, enlazadas entre sí, lo ayudarán a trepar por la torre, esto es, a cumplir su objetivo.

La utilización sexual del personaje de Caperucita queda en evidencia en la imagen 16 , donde dicha protagonista se descontextualiza totalmente y se emplea como reclamo para la promoción de unos bombones. La asociación está servida: el postre, lo dulce, con 
la sensualidad y el erotismo, de ahí que el logo de la marca se sitúe justo debajo del prominente escote de la modelo. Si nos preguntamos qué vemos, nuestro intertexto lector nos hará responder: "a Caperucita"; sin embargo, en esa afirmación ya estamos dando la información inferida: si de esa fotografía eliminamos la capa roja, nada nos haría vincularlo a ese referente. De ahí la importancia de los iconos que se introducen en el discurso publicitario a la hora de obtener el efecto esperado en el público receptor, pese a que en este caso los "roles" se han invertido, y esto refuerza el toque de atención del anuncio: la peligrosa pasa a ser Caperucita, dispuesta a devorar el postre.

\section{Resultados y discusión}

Una vez realizada toda la reflexión anterior, se ponen de manifiesto dos cuestiones que vamos a desarrollar a continuación: por un lado, el gran potencial didáctico de los textos publicitarios para el desarrollo de la educación lingüística literaria en la formación del profesorado; $y$, por otro, la necesidad de ofrecer pequeños itinerarios que dibujen el plan de trabajo posible con algunos de ellos.

\subsection{El potencial didáctico en la educación lingüística y literaria de maestros/as}

Uno de los mejores ejemplos de que el acto de leer va mucho más allá de la mera descodificación del código escrito lo encontramos en el discurso publicitario. En él convergen los distintos lenguajes, que, sabiamente combinados, logran contar una historia, armar un discurso muchas veces cuasi perfecto desde el punto de vista estético y pragmático. Además, es uno de los más presentes en nuestro día a día, especialmente con el auge de las redes sociales, donde la publicidad se "cuela" sin darnos cuenta mientras accedemos a un vídeo de YouTube o subimos una foto al Instagram, así es imprescindible saber cómo "enfrentarnos" a ellos, por un lado, y utilizarlos como recurso pedagógico/didáctico, por otro, puesto que - no olvidemos - son los estudiantes los mayores asiduos a transitar por esos espacios ${ }^{4}$.

4 Tanto es así que estos nuevos espacios han revolucionado la propia creación literaria, por su proximidad con nuestros jóvenes y adolescentes (SÁNCHEZ GARCÍA, 2018).

Educ. Form., Fortaleza, v. 6, n. 1, e3455, jan./abr. 2021

DOI: https://doi.org/10.25053/redufor.v6i1.3455

https://revistas.uece.br/index.php/redufor/index 
Durante mucho tiempo, venimos defendiendo una educación lingüística y literaria desde una perspectiva heurística, apoyada en el aprendizaje significativo, crítico, comprometido y centrado en la integración de destrezas (LÓPEZ VALERO; ENCABO FERNÁNDEZ, 2001; QUILES CABRERA; MARTÍNEZ EZQUERRO; PALMER, 2019). La competencia comunicativa alcanza distintos niveles que no deben desarrollarse de forma independiente, sino que son complementarios. Si este planteamiento es el que impulsamos para el ámbito escolar, no podemos perderlo de vista a la hora de potenciar estas destrezas en los futuros mediadores - los maestros/as en formación. Ese enfoque integrado, además, se va a enriquecer cuando le confiramos un carácter interdisciplinar e intertextual a nuestras propuestas de trabajo con los estudiantes. El discurso publicitario, como manifestación de la cultura urbana en constante evolución, es uno de los textos que más posibilidades nos ofrece para proyectar este enfoque metodológico, puesto que permite desarrollar, tomándolo como input o punto de partida, toda una serie de destrezas que sintetizamos de la siguiente forma y que se van ampliar o amoldar en función del anuncio escogido y de las tareas realizadas:

Tabla 1 - Desarrollo de destrezas

\begin{tabular}{|c|l|}
\hline \multirow{5}{*}{ Destrezas orales } & $\begin{array}{l}\text { - Estructura y elementos de distintas situaciones comunicativas orales, como } \\
\text { puede ser el debate. } \\
\text { - Argumentación de ideas propias, capacidad de escucha y asociación de } \\
\text { ideas. } \\
\text { - Adecuación al registro: habla coloquial versus lenguaje académico. } \\
\text { - Metacomunicación: detección de vicios idiomáticos, eufonías, recitación, etc. }\end{array}$ \\
\hline Destrezas escritas & $\begin{array}{l}\text { - Situaciones comunicativas escritas diversas: narración, descripción, diálogo, } \\
\text { epístola, etc. } \\
\text { - Mecanismos de coherencia y cohesión: marcadores del discurso. } \\
\text { - Capacidad de síntesis. } \\
\text { - Juegos de palabras (dobles sentidos, humor, etc.). } \\
\text { - Contacto con nuevos espacios en red (que pueden servirnos de soporte para } \\
\text { desarrollar habilidades). } \\
\text { - Relectura y recreación de textos literarios clásicos o actuales, que han sido } \\
\text { recuperados en el discurso publicitario en cuestión. } \\
\text { - Lectura crítica y reflexiva de mensajes subliminares. } \\
\text { - Lectura integrada de distintos códigos lingüísticos. } \\
\text { - Lectura de textos académicos de investigación e innovación educativa. }\end{array}$ \\
\hline
\end{tabular}

Educ. Form., Fortaleza, v. 6, n. 1, e3455, jan./abr. 2021

DOI: https://doi.org/10.25053/redufor.v6i1.3455

https://revistas.uece.br/index.php/redufor/index 


\begin{tabular}{|c|c|}
\hline $\begin{array}{c}\text { Comunicación no } \\
\text { verbal y paralenguaje }\end{array}$ & $\begin{array}{l}\text { - Sentido literal versus sentido inferido. } \\
\text { - Lenguaje icónico: imagen, color, disposición de los elementos. } \\
\text { - Gestualidad y proxemia en los actores. } \\
\text { - Música o ruido ambiental (en caso de anuncio audiovisual). } \\
\text { - La semiótica de los silencios (lo que no se dice). }\end{array}$ \\
\hline $\begin{array}{c}\text { Vinculación con otras } \\
\text { artes y temas } \\
\text { transversales }\end{array}$ & $\begin{array}{l}\text { - Descubrimiento del carácter intertextual de la publicidad. } \\
\text { - Aprendizaje interdiciplinar, dada la conexión con otras artes (pintura, música, } \\
\text { cine) y disciplinas (ciencia, tecnología). } \\
\text { - Desarrollo de los temas transversales del currículum: concienciación en torno } \\
\text { a temas sociales muy diversos (género, ecología, interculturalidad, hábitos } \\
\text { de ocio saludables, consumismo, etc.). }\end{array}$ \\
\hline
\end{tabular}

Fuente: Elaboración propia (2020).

\subsection{Algunas líneas de trabajo (o itinerarios) para el aula universitaria}

En la siguiente tabla (número 2), describimos algunas líneas de trabajo para el desarrollo interdisciplinar e intertextual de competencias a partir de distintos textos publicitarios de referencia:

Tabla 2 - Líneas de trabajo para el desarrollo interdisciplinar e intertextual

\begin{tabular}{|c|l|l|}
\hline Contexto de aplicación & $\begin{array}{l}\text { Los itinerarios que planteamos en esta tabla van dirigidos al contexto de la } \\
\text { Educación Superior, concretamente a la formación de maestros/as de Educación } \\
\text { Primaria. Las líneas de trabajo propuestas podrían incorporarse en asignaturas } \\
\text { del área de Didáctica de la Lengua y la Literatura, como es el caso de Didáctica } \\
\text { (según el plan de estudios de cada universidad). También podrían aplicarse de } \\
\text { manera interdisciplinar con otras materias que coincidan en el curso y } \\
\text { cuatrimestre, coordinando los contenidos con el equipo docente. Al mismo } \\
\text { tiempo, serían extrapolables a otros títulos, asignaturas o contextos (como la } \\
\text { enseñanza de español como lengua extranjera en el ámbito universitario), con su } \\
\text { adecuada adaptación a los aprendices y sus necesidades educativas. }\end{array}$ \\
\hline referencia (input) & \multicolumn{1}{|c|}{ Disponible en: https://www.youtube.com/ watch?v=wafe6kdbb6c } \\
\hline
\end{tabular}

Educ. Form., Fortaleza, v. 6, n. 1, e3455, jan./abr. 2021

DOI: https://doi.org/10.25053/redufor.v6i1.3455

https://revistas.uece.br/index.php/redufor/index 


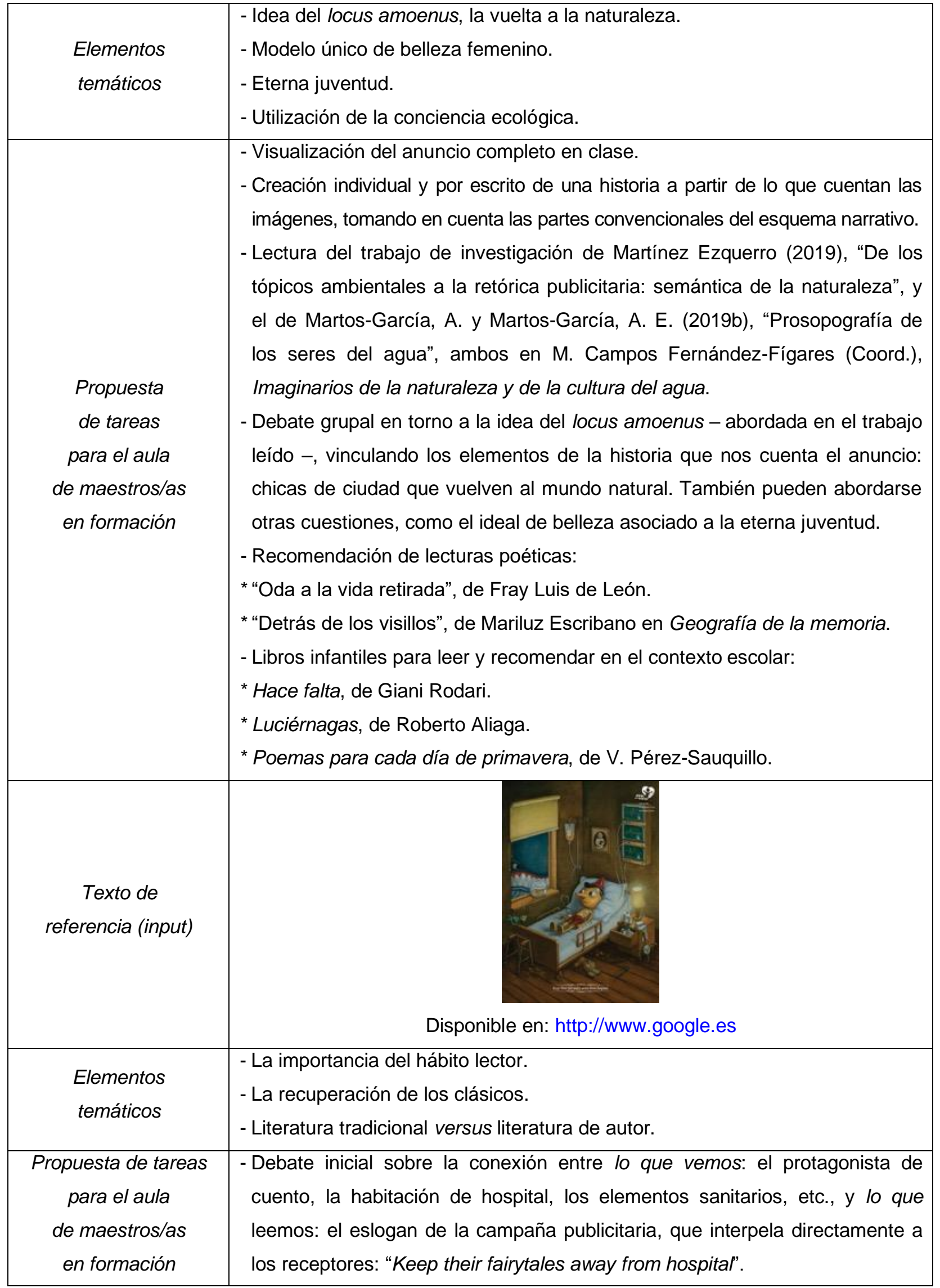

Educ. Form., Fortaleza, v. 6, n. 1, e3455, jan./abr. 2021

DOI: https://doi.org/10.25053/redufor.v6i1.3455 


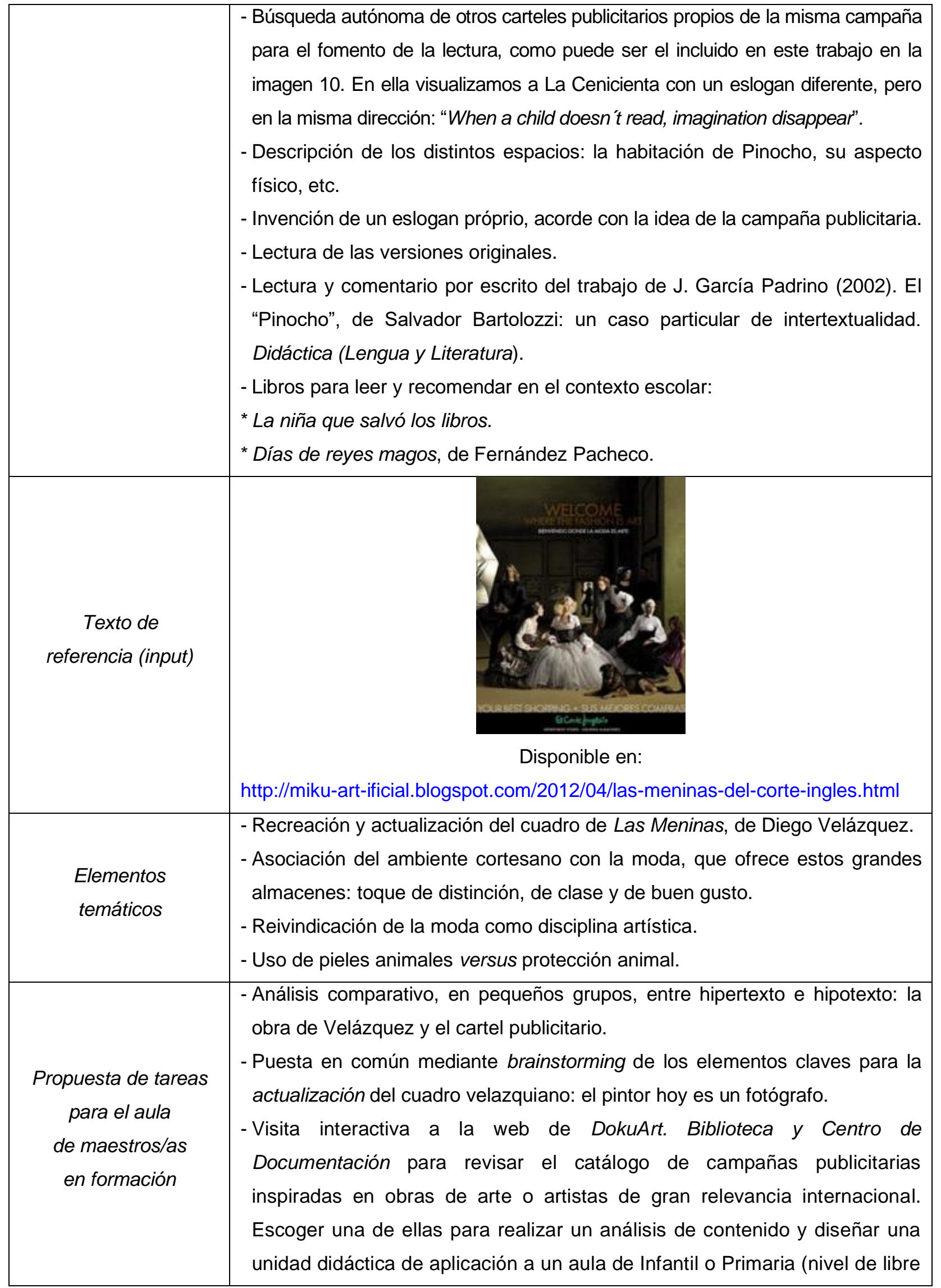

Educ. Form., Fortaleza, v. 6, n. 1, e3455, jan./abr. 2021

DOI: https://doi.org/10.25053/redufor.v6i1.3455

https://revistas.uece.br/index.php/redufor/index 


\begin{tabular}{|l|l|}
\hline & elección en función del perfil profesional del título). Dicho documento está \\
& disponible en: https://catalogo.artium.eus/book/export/html/9564. \\
- Invención de una historia de la escena y los personajes, trasladada al tiempo & actual. \\
- Elaboración de un vídeo promocional del cuadro original del siglo XVII, en el & que se hable tanto de la época como de los distintos personajes. Los \\
estudiantes pueden hacer de actores y preparar su propio guión. Para ello \\
será necesario informarse, investigar, planificar, plasmar por escrito y oralizar \\
su discurso, al tiempo que habrán de manejar diferentes recursos TIC, como \\
programas informáticos para la edición de vídeos o aplicaciones para el \\
teléfono móvil. \\
- Libros para leer y recomendar en el contexto escolar: \\
* Siete historias para la Infanta Margarita, Fernández Pacheco. \\
* La infantita quiere buñuelos, Asun Balzola. \\
* Noche en el Museo del Prado.
\end{tabular}

Fuente: Elaboración propia (2020).

\section{Consideraciones finales}

A lo largo de este trabajo, hemos pretendido establecer un paradigma educativo basado en el enfoque intertextual e interdisciplinar para el desarrollo de la competencia comunicativa en la Educación Superior y, en particular, en la formación de maestros y maestras. Todo ello partiendo de una concepción de confluencia entre el marco epistemológico-teórico con la práctica educativa (MEZZAROBA; CARRIQUIRIBORDE, 2020). Por un lado, hemos puesto de relieve la necesidad de continuar reforzando las destrezas orales y escritas de nuestros estudiantes universitarios; también se ha dejado claro el papel que la publicidad adquiere en el momento actual, con una incursión plena en todos los espacios urbanos - marquesinas de autobús, estaciones de metro, etc. - y en las redes sociales. De ahí la esencialidad de saber leer el discurso publicitario y descubrir las claves para fomentar un espíritu crítico y establecer puentes intertextuales que, desde la promoción de un perfume, por ejemplo, nos lleve a reconocer un clásico literario y a poder interpretar lo que de él se reescribe. Con la última parte, hemos contribuido al diseño de diversas líneas de actuación didáctica con ejemplos concretos basados en la aplicación de tareas bajo la máxima de una perspectiva heurística, integrada y significativa del aprendizaje. 


\section{Referencias}

ARRIVÉ, M. Pour une théorie des textes polisotopiques. Langages, n. 31, p. 53-63, 1973.

BARTHES, R. Texte (théorie du). Encyclopaedia Universalis, v. 15, 1968.

DÄLLENBACH, L. Intertexte et autotexte. Poétique, n. 27, p. 282-296, 1976.

CABALLERO, J. A. Ave Fénix. Retórica y perviviencia del mundo clásico en la publicidad. Kleos: estemporaneo di studi e testi sulla fortuna dell'antico, n. 21, p. 401-442, 2010.

DEL RíO, A. Casa árbol del terror: un discurso sobre la monstruosidad y la intermedialidad en Los Simpson. Fotocinema: revista científica de cine y fotografía, n. 14, p. 205-231, 2017.

DURAÑONA, M. A. et al. Textos que dialogan: la intertextualidad como recurso didáctico. Madrid: Consejería de Educación, 2006.

ENRÍQUEZ VELOSO, G. Intertextualidad en The Simpsons: transgresión y ruptura formal. Proceedings of the 10th World Congress of the International Association for Semiotic Studies (IASS/AIS). A Coruña: Universidad, 2012. p. 1751-1760.

FERNÁNDEZ-FÍGARES, M. C.; GARCÍA RIVERA, G. Aproximación a la ecocrítica y la ecoliteratura: literatura juvenil clásica e imaginarios del agua. Ocnos: Revista de Estudios sobre Lectura, v. 16, n. 2, p. 95-106, 2017. DOI:

https://doi.org/10.18239/ocnos_2017.16.2.1511. Accedido el: 20 sept. 2020.

FREIRE, A. Publicidad en torno al mito: el uso de figuras mitológicas como herramienta persuasiva del discurso publicitario. Historia y Comunicación Social, n. 19, p. 241-251, 2014.

GARCÍA TORRALBO, M. C. Cine, historia y arte en los dibujos animados: la cultura española en "Los Simpson". In: CAMARERO, E.; MARCOS, M. (Coord.). II Congreso Internacional Historia, literatura y arte en el cine español y portugués: de los orígenes a la revolución tecnológica del siglo XXI. Salamanca: Universidad de Salamanca, 2013. p. 522-529.

GENETTE, G. Palimpsestos: La literatura en segundo grado. Madrid: Taurus, 1989.

GRAY, J. Watching with The Simpsons: television, parody and intertextuality. New York: Routledge, 2006.

HORACIO SÁNCHEZ, C. Los diez mejores momentos matemáticos de Los Simpson. Números: Revista de Didáctica de las Matemáticas, n. 73, p. 35-40, 2010.

Educ. Form., Fortaleza, v. 6, n. 1, e3455, jan./abr. 2021

DOI: https://doi.org/10.25053/redufor.v6i1.3455

https://revistas.uece.br/index.php/redufor/index 
IRWIN, W.; CONARD, M. T.; SKOBLE, A. J. Los Simpson y la filosofía. Barcelona: Blackie, 2009.

KRISTEVA, J. Bakhtine, le mot, le dialogue et le roman. Critique, Paris, v. 239, p. 438465, 1967.

LARA, C. Las voces y ecos: perspectivas sobre la intertextualidad. Málaga: Universidad de Málaga, 2007.

LOMAS, C. El espectáculo del deseo, usos y formas de la persuasión publicitaria. Barcelona: Octaedro, 1996.

LOMAS, C. Los lenguajes de la persuasión. Cuadernos de Pedagogía, n. 216, p. 35-39, 1993.

LOMAS, C. Textos y contextos de la persuasión. Los medios de comunicación de masas y la construcción social del conocimiento. Enunciación, v. 6, n. 1, p. 6-12, 2001. DOI: https://doi.org/10.14483/22486798.2436

LÓPEZ, Z. A análise multimodal da publicidade audiovisual para as aulas de Língua e Literatura Espanhola no Ensino Secundário e no Ensino Médio. Educação \& Formação, Fortaleza, v. 5, n. 3, 2020. DOI: https://doi.org/10.25053/redufor.v5i15set/dez.2839. Disponible en: https://revistas.uece.br/index.php/redufor/article/view/2839. Accedido el: 20 sept. 2020.

LÓPEZ, Z. La publicidad en el aula de Lengua Castellana y Literatura en Enseñanza Secundaria en España: retos y desafíos. Lenguaje y Textos, n. 45, p. 89-100, 2017. DOI: https://doi.org/10.4995/lyt.2017.7365

LÓPEZ-BARAJAS, E. Estrategias de formación en el siglo XXI: life long learning. Barcelona: Ariel, 2006.

LÓPEZ VALERO, A.; ENCABO FERNÁNDEZ, E. Heurística de la comunicación: las aulas felices. Barcelona: Octaedro, 2001.

LÓPEZ VAleRO, A. Prólogo. In: F.-FíGAReS, M. C.; QUILES CABRERA, M. C. (Ed.). Repensando la didáctica de la lengua y la literatura: paradigmas y líneas emergentes de investigación. Madrid: Visor, 2019. p. 15-25.

MARTíN, A. J.; MARTíN, M. El cine de animación como recurso didáctico en el aula de matemáticas: Los Simpson. Sigma: Revista de Matemáticas, n. 35, p. 119-131, 2010.

MARTÍNEZ EZQUERRO, A. De los tópicos ambientales a la retórica publicitaria: semántica de la naturaleza. In: F.-FÍGARES, M. C. (Coord.). Imaginarios de la naturaleza $y$ de la cultura del agua. Madrid: Marcial Pons, 2019. p. 127-144. 
MARTÍNEZ EZQUERRO, A. Estrategias para analizar el discurso retórico publicitario: un modelo a través de anuncios de España y Portugal. Contextos Educativos, n. 27 (en prensa), 2021.

MARTÍNEZ EZQUERRO, A. Revisión metodológica e innovación en el ámbito universitario. Retórica y comunicación audiovisual. Revista del CIDUI, n. 1, p. 1-17, 2012.

MARTÍNEZ, J. E. La intertextualidad literaria: base teórica y práctica textual. Madrid: Cátedra, 2001.

MARTOS-GARCÍA, A.; MARTOS-GARCÍA, A. E. Dialogismo y representaciones de las ninfas en la tradición folclórica, literaria y artística. Aisthesis: Revista Chilena de Investigaciones Estéticas, n. 66, p. 37-60, 2019a.

MARTOS-GARCÍA, A.; MARTOS-GARCÍA, A. E. Prosopografía de los seres del agua: patrones narrativos y taxonómicos de los genios de la naturaleza y de sus entornos. In: F.-FíGARES, M. C. (Coord.). Imaginarios de la naturaleza y de la cultura del agua. Madrid: Marcial Pons, 2019b. p. 127-144.

MARTOS NÚÑEZ, E. Las damas blancas como tipo cuentístico y leyendístico tradicional. Revista de Estudios Extremeños, n. 53, v. 2, p. 625-654, 1997.

MENDOZA FILLOLA, A. Literatura comparada e intertextualidad: una propuesta para la innovación curricular de la literatura. Madrid: La Muralla, 1994.

MENDOZA FILLOLA, A. Los intertextos: del discurso a la recepción. In: MENDOZA, A.; CERRILLO, P. (Coord.). Intertextos: aspectos sobre la recepción del discurso artístico. Cuenca: Universidad de Castilla-La Mancha, 2003.

MEZZAROBA, C.; CARRIQUIRIBORDE, N. Teoria e prática: questões imprescindíveis a prática educativa. Educação \& Formação, Fortaleza, v. 5, n. 3, 2020. DOI:

https://doi.org/10.25053/redufor.v5i15set/dez.2807. Disponible en:

https://revistas.uece.br/index.php/redufor/article/view/2807. Accedido el: 20 sept. 2020.

MONTOYA, J. A. Mitologías de la publicidad: un análisis semiótico del mito publicitario. 2015. Tesis, Universidad de Granada, Granada, 2015.

QUILES CABRERA, M. C. Entre pinceles y libros: textos para un enfoque intertextual e interdisciplinar en el aula de lengua. Álabe, n. 6, p. 1-19, 2012. DOI:

http://dx.doi.org/10.15645/Alabe.2012.6.5. Disponible en:

http://revistaalabe.com/index/alabe/article/view/115/104. Accedido el: 20 sept. 2020.

QUILES CABRERA, M. C. La competencia comunicativa en la Educación Superior: en torno a los indicadores para su seguimiento y evaluación. ED.UCO: Revista de Investigación Educativa, n. 5, p. 59-74, 2011. 
QUILES CABRERA, M. C. La intertextualidad en el aula de español como lengua extranjera: música, texto e imagen. Textos de Didáctica de la Lengua y la Literatura, n. 54, p. 113-123, 2010.

QUILES CABRERA, M. C.; MARTÍNEZ EZQUERRO, A.; PALMER, I. Enredos de palabras: gramática y uso de la lengua en nuevos espacios de comunicación. Barcelona: Graó, 2019.

ROBLES ÁVILA, S. Lectura y escritura del mensaje comercial: los extranjerismos de los sectores publicitarios de la tecnología de la información y de las comunicaciones. Álabe, n. 10, p. 1-18, 2014. DOI: http://dx.doi.org/10.15645/alabe.2014.10.7. Disponible en: http://revistaalabe.com/index/alabe/article/view/250. Accedido el: 20 sept. 2020.

ROBLES ÁVILA, S. Realce y apelación en el lenguaje de la publicidad. Madrid: Arco, 2004.

RODRÍGUEZ ARRIETA, J. D. Los Simpson y la representación de la política. Reflexiones, n. 94, v. 1, p. 109-121, 2015.

ROMERO OLIVA, M. F. (Coord.). La escritura académica: diagnóstico y propuesta de actuación. Una visión desde los grados de magisterio. Barcelona: Octaedro, 2014.

SÁNCHEZ CORRAL, L. Leer el cuerpo (publicitario) como sujeto que enuncia. Ocnos, n. 2, p. 23-37, 2006. DOI: https://doi.org/10.18239/ocnos_2006.02.02. Disponible en: https://helvia.uco.es/xmlui/bitstream/handle/10396/8397/sanchezcorral1. pdf? sequence=1 \&isallowed=y. Accedido el: 20 sept. 2020.

SÁNCHEZ CORRAL, L. Retórica y sintaxis de la publicidad (itinerarios de persuasión). Córdoba: Universidad, 1991.

SÁNCHEZ CORRAL, L. Semiótica de la publicidad: narración y discurso. Madrid: Síntesis, 1997.

SÁNCHEZ GARCÍA, R. (coord). Nuevas poéticas y redes sociales. Madrid: Siglo XXI, 2018.

SANTOS RECUENCO, E. Literatura infantil y juvenil y publicidad en nuestros días. In: SÁNCHEZ ORTIZ, C.; SANZ TEJEDA, A. (Coord.). La voz de la memoria, nuevas aproximaciones al estudio de la literatura popular de tradición infantil: $V$ Jornadas Iberoamericanas de Literatura Popular Infantil. Homenaje a Pedro Cerrillo. 2019. p. 201219.

VÁZQUEZ MEDEL, M. A. El dinamismo textual: introducción a la semántica de la transtextualidad. Sevilla: Cuadernos de Comunicación, 1995. 
María del Carmen Quiles Cabrera, Universidad de Almería, Departamento de Educación, Facultad de Ciencias de la Educación

iDhttps://orcid.org/0000-0002-9202-6608

Doctora en Filología Hispánica y profesora titular de universidad en el área de Didáctica de la Lengua y la Literatura de la Universidad de Almería. Ha publicado trabajos como La comunicación oral. Propuestas didácticas para la educación primaria (Ed. Octaedro); Hablar, leer y escribir: el descubrimiento de las palabras y la educación lingüística y literaria (Ed. Visor), en coautoría con Ítaca Palmer y María Rosal; y Enredos de palabras: gramática y uso de la lengua en nuevos espacios de comunicación (Ed. Graó), en coatoría con Martínez Ezquerro y Palmer. Cuenta con contribuciones en revistas de impacto, como Porta Linguarum, Oralia, Tonos Digital o Pedagogía Social. Además, ha publicado numerosos capítulos de libro en editoriales, como Síntesis, Octaedro o Marcial Pons, así como ha coordinado obras colectivas.

Contribución de autoría: Redacción y revisión del artículo.

E-mail: qcabrera@ual.es

Editora responsable: Lia Machado Fiuza Fialho

Pareceristas ad hoc: Virginia Calvo y Zósimo Pena

\section{Cómo citar este artículo (ABNT):}

QUILES CABRERA, María del Carmen. Discurso publicitario e intertextualidad: itinerarios para la formación comunicativa del profesorado. Educ. Form., Fortaleza, v. 6, n. 1, e3455, 2020. Disponible en: https://revistas.uece.br/index.php/redufor/article/view/3455

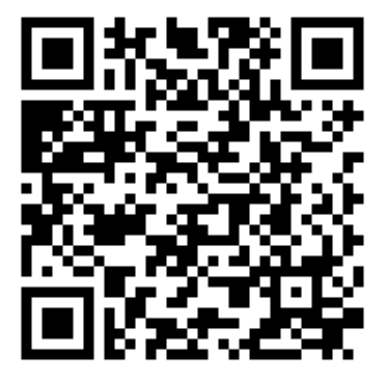

Recibido el 9 de julio de 2020.

Aceptado el 4 de agosto de 2020.

Publicado el 4 de noviembre de 2020.

Educ. Form., Fortaleza, v. 6, n. 1, e3455, jan./abr. 2021

DOI: https://doi.org/10.25053/redufor.v6i1.3455

https://revistas.uece.br/index.php/redufor/index 